\title{
Multiple Serotonergic Mechanisms Contributing to Sensitization in Aplysia: Evidence of Diverse Serotonin Receptor Subtypes
}

\author{
Demian Barbas, ${ }^{1}$ Luc DesGroseillers, ${ }^{1,2}$ Vincent F. Castellucci, ${ }^{2,3}$ Thomas J. Carew, ${ }^{4,5}$ \\ and Stéphane Marinesco ${ }^{4}$ \\ ${ }^{1}$ Département de biochimie, ${ }^{2}$ Centre de Recherche en Sciences Neurologiques, and ${ }^{3}$ Département de physiologie, Université de \\ Montréal, Québec H3C 3J7, Canada; ${ }^{4}$ Department of Neurobiology and Behavior, CNLM, University of California-Irvine, \\ Irvine, California 92697, USA
}

\begin{abstract}
The neurotransmitter serotonin (5-HT) plays an important role in memory encoding in Aplysia. Early evidence showed that during sensitization, 5-HT activates a cyclic AMP-protein kinase A (CAMP-PKA)-dependent pathway within specific sensory neurons (SNs), which increases their excitability and facilitates synaptic transmission onto their follower motor neurons (MNs). However, recent data suggest that serotonergic modulation during sensitization is more complex and diverse. The neuronal circuits mediating defensive reflexes contain a number of interneurons that respond to 5-HT in ways opposite to those of the SNs, showing a decrease in excitability and/or synaptic depression. Moreover, in addition to acting through a cAMP-PKA pathway within SNs, 5-HT is also capable of activating a variety of other protein kinases such as protein kinase $C$, extracellular signal-regulated kinases, and tyrosine kinases. This diversity of 5-HT responses during sensitization suggests the presence of multiple 5-HT receptor subtypes within the Aplysia central nervous system. Four 5-HT receptors have been cloned and characterized to date. Although several others probably remain to be characterized in molecular terms, especially the Gs-coupled 5-HT receptor capable of activating cAMP-PKA pathways, the multiplicity of serotonergic mechanisms recruited into action during learning in Aplysia can now be addressed from a molecular point of view.
\end{abstract}

The marine mollusk Aplysia has proven to be a powerful model system for the study of learning and memory. This animal displays several simple forms of nonassociative learning, such as habituation, dishabituation, and sensitization (Pinsker et al. 1970, 1973; Carew et al. 1971), but also more complex forms of associative learning such as classical, operant, and fear conditioning (Carew et al. 1981, 1983; Walters et al. 1981; Lechner et al. 2000a,b; Brembs et al. 2002). The strength of this model system arises from the relative simplicity of its central nervous system (CNS), which contains a small number of neurons, some of which are well characterized both morphologically and electrophysiologically. Thus, one can study a specific synaptic connection in different animals subjected to a wide variety of behavioral training protocols. For this reason, it has been possible to discover many of the mechanisms of learning and memory in this animal at the behavioral, cellular, and molecular levels, and provide direct evidence that certain forms of learning rely on the plasticity of individual synaptic connections (for review, see Kandel 2001).

One of the best characterized forms of learning in Aplysia is sensitization, in which a noxious stimulus facilitates an animal's pre-existing response to the presentation of another innocuous stimulus. It has been most thoroughly studied in the defensive reflex responses of Aplysia. For example, a mild tactile stimulus applied to the tail evokes the retraction of respiratory organs (gill and siphon) inside the mantle cavity situated on the back of the animal. The strength and duration of this reflex can be enhanced by a noxious electrical stimulation applied to the tail, the head,

\footnotetext{
${ }^{5}$ Corresponding author.
}

E-MAIL tcarew@uci.edu; FAX (949) 824-5161.

Article and publication are at http://www.learnmem.org/cgi/doi/10.1101/ Im.66103. or the body wall. Memory for this form of sensitization relies at least in part on the strengthening of sensory neuron $(\mathrm{SN})$ to motor neuron (MN) transmission, namely, increase in SN excitability and facilitation of SN-MN synapses. A large amount of experimental data suggests that $\mathrm{SN}-\mathrm{MN}$ synaptic plasticity depends on the release of the neurotransmitter 5-HT within the Aplysia CNS during sensitization training (Brunelli et al. 1976; Mackey et al. 1989; Marinesco and Carew 2002). It is believed that 5-HT activates cyclic adenosine $3^{\prime}: 5^{\prime}$-monophosphate-protein kinase A (cAMP-PKA)-dependent biochemical cascades within SNs, leading to enhanced SN-MN transmission (Brunelli et al. 1976; Castellucci et al. 1980, 1982; Bernier et al. 1982; Abrams et al. 1984; Ocorr and Byrne 1985; Ocorr et al. 1986; Ghirardi et al. 1992; Klein 1993). However, it has become clear that memory processes in Aplysia involve more than the activation of cAMP-PKA pathways within SNs. In particular, it has been demonstrated that in addition to modulating $\mathrm{SN}-\mathrm{MN}$ transmission, 5-HT also acts on several other neuronal cell types within the defensive reflex circuits, and that these actions may involve multiple 5-HT receptor subtypes. In this review, we first summarize the experimental evidence supporting the existence of several serotonergic processes during sensitization. We then review the available data on the different 5-HT receptor subtypes expressed in Aplysia tissues and discuss their possible involvement in learning and memory.

\section{The Role of 5-HT in Memory and Synaptic Facilitation in Aplysia}

The role of 5-HT in sensitization was first suggested in a series of papers by Brunelli et al. (1976) and Castellucci and Kandel (1976), who showed that sensitization of the gill-withdrawal reflex was correlated with an increase in the amount of transmitter 
released by sensory neurons (SNs) at their synapses with motor neurons (MNs), a phenomenon termed presynaptic facilitation (Castellucci and Kandel 1976). This phenomenon could be mimicked by exogenous application of 5-HT or intracellular injection of cAMP, and blocked by the 5-HT antagonist cinanserin (5- $\mathrm{HT}_{2}$ antagonist; Brunelli et al. 1976), and was later shown to be blocked by cyproheptadine (5- $\mathrm{HT}_{1-2}$ antagonist; Mercer et al. 1991). Although the specificity of these drugs for Aplysia 5-HT receptors has not been fully characterized, these data suggest that 5-HT is responsible for the presynaptic facilitation observed during sensitization.

Considerable experimental work was then devoted to identifying the serotonergic neurons responsible for presynaptic facilitation, and determining whether 5-HT was indeed released in the Aplysia CNS during sensitization training. Mackey et al. (1989) showed that a pair of symmetrical 5-HT neurons in the cerebral ganglion, the CC3 (CB1) cells (see Xin et al. 2001 for change in nomenclature) were activated by noxious electrical stimulation of the tail. Moreover, activation of one CC3 (CB1) cell by intracellular current injection was sufficient to produce facilitation of $\mathrm{SN}-\mathrm{MN}$ synapses as well as spike broadening in $\mathrm{SNs}$ in the abdominal ganglion (Mackey et al. 1989; see also Wright et al. 1995). However, as Mackey and colleagues point out, CC3 (CB1) modulation of SN-MN transmission was modest and shortlived compared to modulation by exogenously applied 5-HT. Moreover, it is not known whether the effects of CC3 (CB1) stimulation can be blocked by specific 5-HT receptor antagonists. Thus, the precise role of CC3 (CB1) during sensitization and the respective effects exerted by 5 -HT or by possible cotransmitters that could be released by this neuron remain to be determined. Using direct electrochemical methods, Marinesco and Carew (2002) were able to detect a transient release of 5-HT in the Aplysia CNS in response to electrical stimulation of the tail-nerve P9, an analog of the noxious stimulation of the tail used to produce sensitization. This release lasted about 30-40 sec and peaked around 100-200 nM in the neuropil surrounding tail SN-MN synapses or SN cell bodies (Marinesco and Carew 2002). Increased 5-HT levels in the hemolymph have also been detected during long-term sensitization (Levenson et al. 1999).

For many years, the receptors mediating the actions of 5-HT during learning remained unknown. The lack of information on the 5-HT receptors expressed in the Aplysia CNS has made it difficult to investigate the role of 5-HT in memory at the behavioral level. Indeed, few pharmacological tools are available for accurate manipulation of 5-HT pathways in freely moving animals. The first and only behavioral study to date was performed by Glanzman et al. (1989). These authors chemically lesioned the serotonergic system in Aplysia using high doses of the neuronal toxin 5,7-dihydroxytryptamine (5,7-DHT). They point out that lesioned animals showed major behavioral impairment such as inability to produce locomotion or attach to a substrate. The animals nonetheless displayed defensive reflexes susceptible to habituation. Glanzman and colleagues (1989) observed that dishabituation and synaptic facilitation were greatly decreased in lesioned animals, suggesting that 5-HT release during training is necessary for this form of memory. The effects of this drug on sensitization were not determined (Glanzman et al. 1989). As we will discuss below, designing ways to interfere with specific Aplysia 5-HT receptor subtypes in freely moving animals would allow confirmation and further exploration of this important finding.

\section{Modulation of Defensive Reflex Circuits by 5-HT During Sensitization}

The Aplysia CNS, with its relatively small number of neurons, is a useful model system for mapping neuronal circuits controlling specific aspects of behavior. In this regard, the neuronal circuits mediating defensive reflexes have been extensively studied. Specifically, these include the tail-induced and siphon-induced tail/ siphon withdrawal reflexes (Fig. 1). These reflexes involve three central ganglia: the pleural, pedal, and abdominal ganglia. A tactile stimulus applied to the tail or siphon activates tail or siphon SNs, which excite MNs through monosynaptic (SN-MN synapses) and polysynaptic pathways (for a more detailed review, see Cleary et al. 1995; Frost and Kandel 1995). More than 10 types of interneurons are known to participate in these polysynaptic pathways between SNs and MNs: (1) L25, R25, L26, and L33 are recruited during siphon withdrawal reflex and respiratory pumping (Kanz et al. 1979; Byrne 1983; Eberly and Pinsker 1984; Frost and Kandel 1995), (2) L16, L29, L30, L33, and L34 mediate siphon withdrawal reflex only, and (3) Pl 4 and Pl 17 are involved in reflex tail withdrawal (Buonomano et al. 1992; Cleary and Byrne 1993; Xu et al. 1994). Moreover, Pl 17 is viewed as possibly providing a linkage between pleural and abdominal reflex circuits (Cleary and Byrne 1993). Four types of interneurons are excitatory (L25, R25, L29, and L34), five are inhibitory (L16, L26, L30, L33, and Pl 4), and Pl 17 seems to be excitatory to tail MNs and inhibitory to tail SNs (Fig. 1; Cleary et al. 1995). When excitatory and inhibitory interneurons are recruited during siphon reflex retraction, their synaptic potentials sum at the level of MNs and various interneurons. Although inhibitory interneurons (L16, L30, Pl 4; see Fig. 1) are present within the circuit, activation of this polysynaptic pathway usually results in a stronger and longer excitation of siphon MNs. Therefore, the role of polysynaptic pathways is usually viewed as amplifying and prolonging the monosynaptic excitation coming from SNs (Trudeau and Castellucci 1992; White et al. 1993; Antonov et al. 1999).

Many neurons within this circuit are modulated by both sensitization training and by 5-HT application. Interestingly, 5-HT release in response to tail-nerve shock has been directly demonstrated in the pleural, pedal, and abdominal ganglia, which are the sites of the neuronal circuits for reflex tail or siphon withdrawal (Marinesco and Carew 2002; Bristol et al. 2003). 5-HT is therefore in a position to modulate virtually all of the neuronal elements involved in this circuit during sensitization training.

Fitzgerald and Carew (1991) and Trudeau and Castellucci $(1992,1993)$ sought to distinguish the modulation of mono- and polysynaptic pathways during sensitization. They determined that, whereas monosynaptic $\mathrm{SN}-\mathrm{MN}$ connections were facilitated by 5 -HT, polysynaptic pathways were usually inhibited (Fitzgerald and Carew 1991; Trudeau and Castellucci 1992, 1993). At least four sets of synapses have been shown to be inhibited by 5-HT (Fig. 1): L16 $\rightarrow$ LE (Storozhuk and Castellucci 1999a), L29 $\rightarrow$ LFS (Frost et al. 1988; Bristol et al. 2001), L30 $\rightarrow$ L29 (Frost et al. 1988; Fisher and Carew 1993), and Pl $4 \rightarrow$ tail SNs and MNs (Xu et al. 1995). Some of these synapses (L29 $\rightarrow$ LFS, L30 $\rightarrow$ L29) can undergo the same type of modulation during sensitization training (Frost et al. 1988; Fischer and Carew 1993; Bristol et al. 2001). Moreover, 5-HT decreases the excitability of Pl 4, whereas it usually enhances excitability in tail and siphon SNs. Finally, the siphon is innervated by at least four populations of SNs (LE, rLE, RE, and RF; Frost and Kandel 1995), that can be differentially modulated by 5-HT. For example, 5-HT increases LEs' excitability and facilitates their synapses onto follower neurons, whereas it depresses RF synapses (Fig. 1; Storozhuk and Castellucci 1999b).

5-HT modulation in interneurons is not limited to synaptic plasticity or excitability changes. The synapses from the inhibitory L30 interneurons onto L29 excitatory interneurons provide an example of complex modulation that is mediated both by 5-HT and by sensitization training. These inhibitory synapses undergo a form of activity-dependent short-term synaptic en-

\section{Learning \& Memory}

www.learnmem.org 


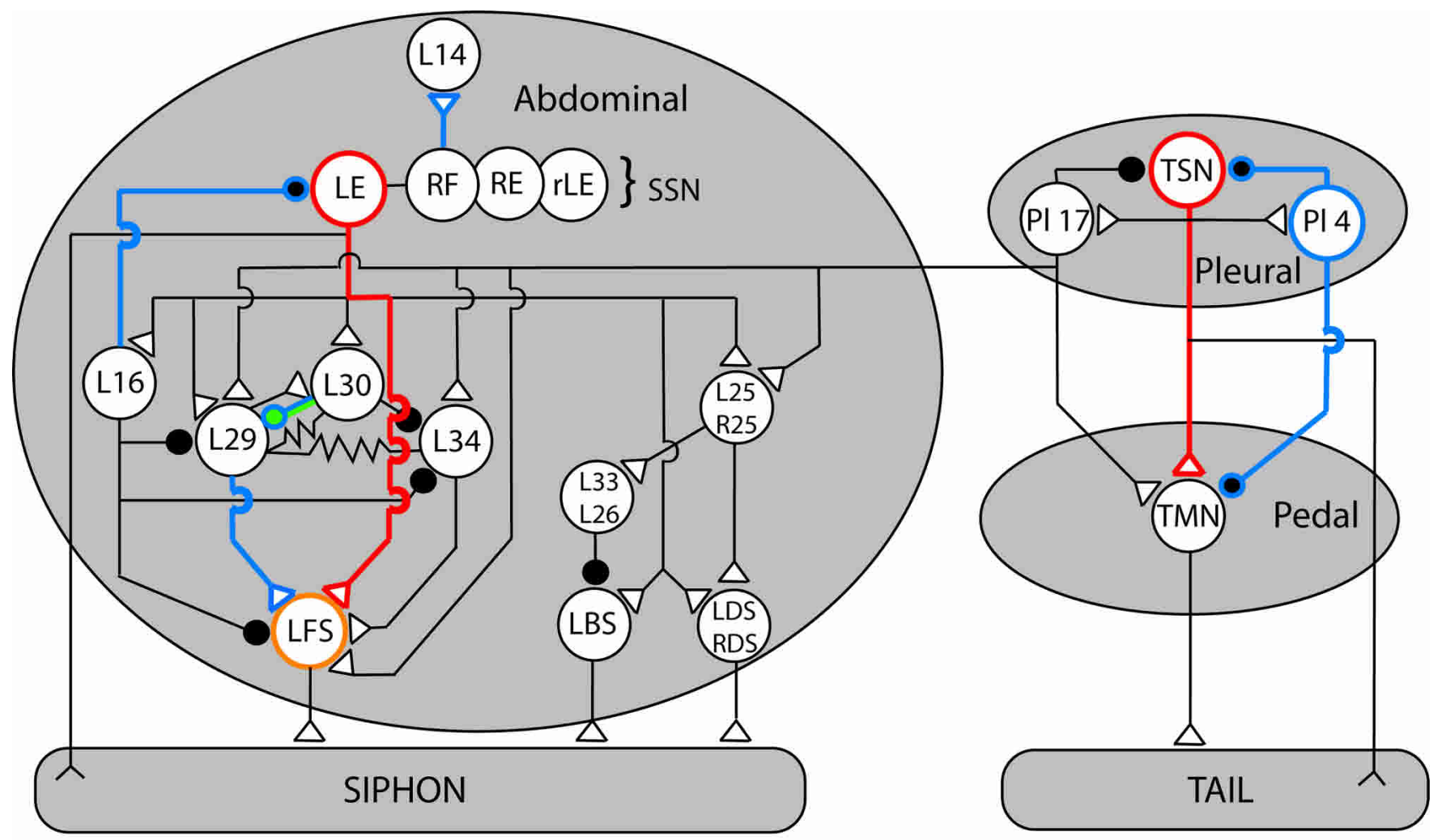

$\triangle$ Inhibition $\longrightarrow$ Excitation $M$ Electrical Junction
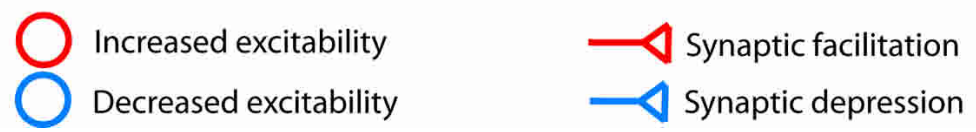

Metaplasticity

Increased glutamate responses

Figure 1 Schematic diagram of the neuronal circuit mediating tail and siphon withdrawal reflex. Neuronal cell bodies are located in three central ganglia (pleural, pedal, and abdominal). A tactile stimulus applied to the tail or siphon activates tail (TSN) or siphon sensory neurons (SSN), which excite MNs through monosynaptic ( $\mathrm{NN}-\mathrm{MN}$ synapses) and polysynaptic pathways depending on interneurons. 5-HT exerts multiple actions on the circuit: It usually induces synaptic depression and/or decreases in excitability in interneurons (blue) and synaptic facilitation and increase in excitability in SNs (red). L14, an ink gland MN, illustrates 5-HT-induced synaptic depression in RF SNs. 5-HT also induces metaplasticity at L30-L29 synapses (green) and increases glutamate responses in LFS MNs (orange). Adapted from Cleary et al. 1995.

hancement induced by the activation of the L30 neurons (Fischer and Carew 1993, 1995). For example, when L30 interneurons fire in response to a mild tactile stimulation, synaptic efficacy at the L30-L29 synapses is enhanced, thus contributing to inhibition of the siphon-withdrawal reflex circuit (Fischer and Carew 1995; Fischer et al. 2000). Both 5-HT and sensitization training block the expression of this form of synaptic plasticity, thereby reducing the potential for inhibition within the circuit. This higherorder form of plasticity reflects an example of "metaplasticity" (Fischer et al. 1997).

In addition to $\mathrm{SN}$ and interneuron modulation, a direct action of 5-HT on MNs has also been described. It involves facilitation of AMPA-type responses to glutamate, the putative neurotransmitter released by SNs, in cultured LFS neurons (Chitwood et al. 2001), and could possibly take place during sensitization training.

We should note that the neuronal circuits mediating defensive reflexes can also be modulated through a variety of nonserotonergic mechanisms. For example, small cardioactive peptide $\mathrm{B}\left(\mathrm{SCP}_{\mathrm{B}}\right)$ facilitates $\mathrm{SN}-\mathrm{MN}$ synapses (Abrams et al. 1984; Pieroni and Byrne 1992) and L16 $\rightarrow$ LE connections (Storozhuk and Castellucci 1999a), and has excitatory effects on Pl 4 (Xu et al. 1995).
Phe-Met-Arg-Phe-amide (FMRFamide) has been shown to inhibit SN-MN transmission (Mackey et al. 1987; Dale and Kandel 1990; Critz et al. 1991; Pieroni and Byrne 1992; Sun et al. 1996), increase the SN firing threshold (Billy and Walters 1989), and modulate specific postsynaptic MNs involved in defensive reflexes (Belkin and Abrams 1993). However, it is not known whether these peptides are released in the CNS during sensitization training. Facilitation of $\mathrm{SN}-\mathrm{MN}$ transmission can also be induced by intracellular stimulation of interneurons L29 and L28 (Hawkins 1981a,b). These interneurons act directly on siphon SNs using an unknown transmitter; it has been determined that the transmitter is not 5-HT (Kistler Jr. et al. 1985; Hawkins and Schacher 1989). Finally, an increasing amount of evidence indicates that, in addition to heterosynaptic processes involving the release of modulatory transmitters onto the neuronal circuit, homosynaptic activity-dependent plasticity also occurs during learning, namely posttetanic potentiation (Walters and Byrne 1984; Frost et al. 1988; Schacher et al. 1990; Bristol et al. 2001) and long-term potentiation (Murphy and Glanzman 1996, 1997; Antonov et al. 2001, 2003). These types of synaptic plasticity are beyond the scope of this review.

Overall, these data indicate that modulation of defensive 
reflex circuits by 5-HT involves a variety of different cell types that respond differently to $5-\mathrm{HT}$. As we will discuss below, it is likely that, when released in the Aplysia CNS during sensitization training, 5-HT acts on several subtypes of receptors that are differentially expressed by SNs, interneurons, and MNs and modulate synaptic transmission and excitability in different ways.

\section{Biochemical Pathways Activated by 5-HT in SNs}

Although the neuronal circuit mediating siphon reflex retraction involves many different cell types, most of which can be modulated by 5-HT, most experimental studies on synaptic plasticity in Aplysia have focused on SNs and SN-MN synapses. Indeed, the $\mathrm{SN}-\mathrm{MN}$ synapses have provided a valuable locus where the cellular and molecular mechanisms underlying memory have been studied. SN-MN synapses are activated during tail or siphon reflex retraction, and their plasticity contributes significantly to simple forms of memory such as sensitization, dishabituation, and classical conditioning (Trudeau and Castellucci 1992; Antonov et al. 1999, 2001, 2003). For example, LE $\rightarrow$ LFS synapses account for about $30 \%$ of the siphon-induced siphon withdrawal reflex efficacy (Antonov et al. 1999). Moreover, behavioral sensitization and $\mathrm{SN}-\mathrm{MN}$ facilitation display similar temporal profiles and molecular mechanisms. For example, a single noxious stimulus usually gives rise to short-term sensitization lasting 20-30 min, whereas four or five spaced shocks induce intermediate-term and long-term sensitization lasting $90 \mathrm{~min}$ and several days, respectively (Pinsker et al. 1973; Castellucci and Kandel 1976; Sholz and Byrne 1987; Sutton et al. 2001, 2002). Similarly, a single exogenous 5-HT application gives rise to shortterm facilitation, whereas five applications produce intermediate-term and long-term facilitation at SN-MN synapses (Frost et al. 1985; Montarolo et al. 1986; Sholz and Byrne 1987; Ghirardi et al. 1995; Mauelshagen et al. 1996; Sutton and Carew 2000). In addition, sensitization and facilitation of SN-MN synapses share common molecular requirements: (1) short-term sensitization and facilitation rely on covalent modification of proteins, (2) intermediate-term, on synthesis of new proteins, and (3) longterm, on RNA and protein synthesis (Castellucci et al. 1986, 1989; Montarolo et al 1986; Ghirardi et al. 1995; Sutton et al. 2001). Finally, a detailed analysis of various neuronal loci during long-term sensitization revealed that, although short-term sensitization is correlated with synaptic plasticity at multiple cell types (SNs, interneurons, etc.), the neuronal correlates of longterm sensitization appear more restricted to SNs (Cleary et al. 1998). For these reasons, most of the studies aimed at understanding the mechanisms of synaptic plasticity in Aplysia have used facilitation of $\mathrm{SN}-\mathrm{MN}$ connections as a model system, leaving 5-HT inhibition in interneurons almost completely unexplored.

Considerable evidence indicates that a single application of 5-HT onto SNs can activate both PKA and protein kinase C (PKC; for review, see Byrne and Kandel 1996). For example, elevation of intracellular cAMP levels and increased PKA activity can be detected following a single pulse of 5-HT (Bernier et al. 1982; Castellucci et al. 1982; Abrams et al. 1984; Ocorr and Byrne 1985; Ocorr et al. 1986; Müller and Carew 1998). Similarly, 5-HT leads to the translocation to the membrane of the $\mathrm{Ca}^{2+}$-dependent isoform of PKC (Saktor and Schwartz 1990; Kruger et al. 1991; Sossin and Schwartz 1992; Braha et al. 1993; Sossin et al. 1993) and an increase in PKC activity (Sossin et al. 1994). Interestingly, recent studies by Manseau et al. (2001) indicated that blocking a $\mathrm{Ca}^{2+}$-independent PKC isoform disrupted facilitation induced by 5-HT at depressed $\mathrm{SN}-\mathrm{MN}$ synapses, whereas blocking the $\mathrm{Ca}^{2+}$ dependent isoform had no effect. Both PKA and PKC are thought to (1) phosphorylate specific ion channels that increase mem- brane excitability and induce spike broadening, and (2) modulate vesicle mobilization and exocytosis to increase transmitter release. For example, PKA, by phosphorylating S-type $\mathrm{K}^{+}$channels, reduces their open time (Siegelbaum et al. 1982). This effect contributes to the increase in membrane excitability and spike broadening following 5-HT application (Klein et al. 1982; Pollock et al. 1985; Baxter and Byrne 1989). Voltage-dependent $\mathrm{K}^{+}$channels $\left(\mathrm{K}_{\mathrm{v}}\right)$ can also be phosphorylated by both PKA and PKC, and seem to be involved specifically in spike broadening (Baxter and Byrne 1989, 1990; Goldsmith and Abrams 1992; Sugita et al. 1992). Spike broadening is an important mechanism for enhancing synaptic transmission through increased $\mathrm{Ca}^{2+}$ influx in nerve terminals. However, 5-HT can increase transmitter release independently of spike broadening, by enhancing the mobilization of transmitter vesicles to the active zone (Klein 1993, 1994). Both PKA and PKC seem capable of producing this effect (Hochner et al. 1986; Braha et al. 1990; Sugita et al. 1992).

Interestingly, PKA and PKC are differentially recruited depending on the duration of 5-HT application and on the state of the synapse. For example, PKA blockers are more effective in preventing synaptic facilitation after short 5-HT applications, whereas PKC blockers are more effective after long exposures (Braha et al. 1990; Hochner and Kandel 1992; Sugita et al. 1992). Similarly, facilitation of depressed synapses is blocked by inhibitors of PKC but not PKA, whereas the converse has been shown for nondepressed synapses (Braha et al. 1990; Goldsmith and Abrams 1991; Ghirardi et al. 1992). This state- and time-dependence of PKA and PKC recruitment by 5-HT (Byrne and Kandel 1996) remains unexplained. It is possible that 5-HT activates two different receptor subtypes coupled to diacylglycerol (DAG) and cAMP, respectively, or that a single receptor subtype could bind to two different $G$ proteins. This question will remain unanswered until 5-HT receptors expressed by SNs have been fully characterized.

In addition to PKA and PKC, repeated pulses of 5-HT, which give rise to long-term facilitation, are able to recruit another set of protein kinases that are not activated by a single application. For example, the mitogen-activated protein kinase (MAPK), also called extracellular-signal-regulated kinase (ERK), is activated in response to repeated pulses of 5-HT and translocates to the nucleus, where it modulates gene expression necessary for longterm facilitation (Martin et al. 1997; Michael et al. 1998; Sharma et al. 2003). Moreover, 5-HT-induced ERK activation and longterm synaptic facilitation both require activation of tyrosine kinases (presumably receptor tyrosine kinases or RTKs; Purcell et al. 2003). What makes repeated 5-HT pulses capable of activating ERK and tyrosine kinases, when a single application is unable to do so? Again, it is likely that a better knowledge of Aplysia 5-HT receptors will help elucidate this important question.

Because of their central role in memory processes and synaptic plasticity, considerable effort has been devoted to characterizing Aplysia 5-HT receptors, from as early as the 1960s. The most striking progress, however, has been obtained within the last 10 years. During this time, the cloning and characterization of four different 5-HT receptors has been reported. We will now turn our attention to a discussion of the properties of these receptors as well as their potential implication in memory processes.

\section{Evolutionary Divergence of 5-HT Receptors}

In general, 5-HT receptors are classified and grouped into seven families on the basis of sequence identity and on the nature of the second-messenger systems to which they are coupled. Six of these families are composed of G-protein-coupled metabotropic receptors (or GPCRs). The 5- $\mathrm{HT}_{1}$ and $5-\mathrm{HT}_{5}$ (Gi-coupled recep- 
tors) inhibit adenylyl cyclase, whereas $5-\mathrm{HT}_{4}, 5-\mathrm{HT}_{6}$, and $5-\mathrm{HT}_{7}$ (Gs-coupled receptors) subtypes activate its activity. Only two subtypes are not linked to the adenylyl cyclase pathway: (1) $5-\mathrm{HT}_{2}$ receptors are coupled to phospholipase C (Gq-coupled receptors) and stimulate phosphoinositide metabolism, and (2) 5- $\mathrm{HT}_{3}$ subtypes are ionotropic receptors and thus are not composed of GPCRs (Hoyer et al. 1994; Peroutka 1995). Previous phylogenetic studies suggested that mammalian 5-HT receptor subtypes emerged from gene duplication, followed by mutations and sequence drift (Vernier et al. 1995; Tierney 2001). Early molecular events first led to the divergence of three major classes of paralogous 5-HT receptors: the $5-\mathrm{HT}_{1}\left(5-\mathrm{HT}_{1,5,7}\right.$ receptors), the $5-\mathrm{HT}_{2}$, and $5-\mathrm{HT}_{6}$ classes which existed about 750 million years ago (Mya). Further division within the $5-\mathrm{HT}_{1}$ class occurred 600 Mya, when $5-\mathrm{HT}_{5}$ and $5-\mathrm{HT}_{7}$ subtypes diverged from the $5-\mathrm{HT}_{1}$ subtype. These divergences predate the evolution of vertebrates from invertebrates, which also occurred about 600 Mya. Therefore, members of the three major classes are likely to be found in invertebrate species. However during evolution, subsequent independent differentiation of each subtype within each class of vertebrate and invertebrate receptors makes it difficult to classify invertebrate 5-HT receptors into specific vertebrate subtypes (Peroutka 1994; Peroutka and Howell 1994; Tierney 2001).

\section{Early Characterization of 5-HT Receptors Expressed by Aplysia Neurons}

5-HT mediates a great variety of functions in Aplysia neurons, probably through multiple G-protein coupled receptors. Serotonergic effects were first reported on neurons (Gerschenfeld and Tauc 1961; Cedar and Schwartz 1972), heart (Koester et al. 1973), and gill (Kebabian et al. 1979). In 1974, Gerschenfeld and Paupardin-Tritsch described six different types of responses following application of 5-HT to Aplysia neurons: four of the responses (named $A, A^{\prime}, B$, and $C$ ) involved an increase in membrane conductance, whereas the other two (named $\alpha$ and $\beta$ ) involved a decrease in membrane conductance (Gerschenfeld and Paupardin-Tritsch 1974). Pellmar and Carpenter (1980) identified a seventh type of response to 5-HT: a voltage- and calcium-dependent response. These different responses were distinguished by voltage clamp experiments in terms of their time course, ionic selectivity, and whether they were mediated by an increase or decrease in membrane conductance. Although these electrophysiological responses could in principle be mediated by a single 5 -HT receptor coupled to different intracellular cascades, these experiments are regarded as the first indications of a variety of potential 5-HT receptor subtypes in the CNS of Aplysia.

The presence of multiple 5-HT receptors was confirmed by biochemical techniques. Saitoh and Shih (1987) found that an agonist of 5- $\mathrm{HT}_{1 \mathrm{~A}}$ receptors, 1-[2-(4-azidophenyl)ethyl]4-(3-trifluoromethylphenyl)piperazine (azido-PAPP), is a suitable photoaffinity labeling probe for 5-HT receptors in Aplysia. They found that five labeled polypeptides were separated by SDS-PAGE upon incubation of $\left[{ }^{3} \mathrm{H}\right]$ azido-PAPP with total neuronal membranes and UV irradiation. The labeling was abolished by 5-HT, which competes for binding on the same receptors. These results suggested the existence of at least five 5-HT receptor subtypes.

As there is increasing interest in characterizing the role of 5-HT as a neurotransmitter in Aplysia, it is important to identify the pharmacological properties of 5-HT receptors in this animal. In vertebrate nervous tissues, receptor binding techniques have proven to be valuable for the identification and pharmacological characterization of 5-HT receptors. In Aplysia, Drummond et al. (1980), using [ $\left.{ }^{3} \mathrm{H}\right] \mathrm{LSD}$ (lysergic acid diethylamide, a nonselective 5-HT receptor agonist) binding assays and 5-HT-induced modulation of adenylyl cyclase activity, reported the first detailed dis- tribution of 5-HT receptors in various neuronal and nonneuronal tissues. Specific 5-HT-sensitive $\left[{ }^{3} \mathrm{H}\right] \mathrm{LSD}$ binding was found in the gill, heart, buccal muscles, and in all ganglia of the CNS of Aplysia. After localization of 5-HT receptors, stimulation of adenylyl cyclase by 5-HT in membranes of Aplysia ganglia, muscles, and connective nerves was measured, indicating the presence of 5-HT Gs-coupled receptors. Increase in 5-HT-sensitive adenylyl cyclase activity correlated well with the amount of 5-HT-sensitive $\left[{ }^{3} \mathrm{H}\right]$ LSD binding sites in most tissues. High density of 5-HT receptors in pleuro-abdominal connective nerves and their presence in the connective tissue sheaths surrounding the ganglia suggest that not all 5-HT receptors are located at cell bodies and synapses.

Kadan and Hartig (1988) then took advantage of the improved sensitivity of ${ }^{125} \mathrm{I}$-isotope labeling to pursue the mapping of 5-HT receptors in Aplysia. They found that ${ }^{125} \mathrm{I}$-LSD labeled a population of high-affinity serotonergic sites in Aplysia ganglia. 5-HT receptors were primarily located within the neuropil, although a subset of neuronal somata was also labeled. Those authors next determined the potency of various pharmacological compounds to compete for ${ }^{125}$ I-LSD binding sites on sections from pedal or abdominal ganglia. The order of potency was: methysergide $\left(5-\mathrm{HT}_{1-2-7}\right.$ antagonist $)>$ cyproheptadine $\left(5-\mathrm{HT}_{1-2}\right.$ antagonist) $>$ mianserin (antagonist/inverse agonist of 5- $\mathrm{HT}_{2}$ receptors) $>$ cinanserin (effective antagonist of 5-HT responses in Aplysia; Brunelli et al. 1976; Newlin et al. 1980) > 5-HT > ketanserin (5- $\mathrm{HT}_{2}$ antagonist) $>$ bufotenine (5- $\mathrm{HT}_{1-2}$ agonist) $>$ 8-OH-DPAT (5- $\mathrm{HT}_{1 \mathrm{~A}}$ agonist). Kadan and Hartig (1988) observed a decrease in the affinity of 5-HT for ${ }^{125}$ I-LSD binding sites in the presence of $\mathrm{Gpp}(\mathrm{NH}) \mathrm{p}$ (5'-guanylylimidodiphosphate), a poorly metabolized analog of guanine nucleotide triphosphate (GTP), suggesting a coupling of 5-HT receptors to G-proteins in Aplysia CNS. These data indicated that ${ }^{125}$ I-LSD binding sites in the Aplysia nervous system are regionally distributed, exhibit specific pharmacological binding properties, and are coupled to G-proteins. This is consistent with labeling of functional heterogeneous 5-HT receptors. By comparing the pharmacological properties of the ${ }^{125} \mathrm{I}-$ LSD labeled sites with the properties of the six distinct serotonergic receptor types identified by Gerschenfeld and PaupardinTritsch (1974), Kadan and Hartig (1988) suggested that LSD antagonizes the neuronal responses mediated by three of the six electrophysiologically characterized 5 -HT receptors (the A, B, and $C$ types). However, the pharmacological profiles for each of these three types differ to some degree from the profile they observed for ${ }^{125} \mathrm{I}$-LSD binding. For example, compounds used by Gerschenfeld and Paupardin-Tritsch (1974) to inhibit the A and C responses did not block ${ }^{125}$ I-LSD binding, even at 10 times the concentrations previously used by Gerschenfeld and PaupardinTritsch (1974).

Evans et al. (1991), also using ${ }^{125}$ I-LSD, provided further characterization of the localization of 5-HT receptors, focusing on the five major neurons which constitute the abdominal ganglion left upper quadrant (L1, L2, L3, L4, and L6). They also investigated in more detail the electrophysiological properties of the responses they produced following activation by 5 -HT. First, intense labeling was only observed on the soma of a symmetrically located pair of cells in the abdominal ganglion of Aplysia californica: L1 and R1. This binding was blocked by micromolar concentrations of 5-HT and lower concentrations of the serotonergic antagonists cyproheptadine and mianserin, confirming Kadan and Hartig's (1988) results. Second, electrophysiological investigation of 5-HT responses of the neurons in the left upper quadrant revealed a range of 5-HT responses. Cells L3 and L6 showed an increased $\mathrm{K}^{+}$conductance in response to 5-HT that is not blocked by cyproheptadine or mianserin. Cells L2 and L4 displayed a biphasic response to 5-HT: an increase in $\mathrm{Na}^{+}$con- 
ductance, which could be blocked by cyproheptadine or mianserin, followed by a voltage-dependent $\mathrm{Ca}^{2+}$ conductance which was blocked by $\mathrm{Co}^{2+}$ but not the serotonergic antagonists. Cell L1 and its symmetrical partner, $\mathrm{R} 1$, in addition to the $\mathrm{Na}^{+}$and $\mathrm{Ca}^{2+}$ responses observed in $\mathrm{L} 2$ and $\mathrm{L} 4$, displayed an increase in $\mathrm{Cl}^{-}$ conductance that can be inhibited by LSD, cyproheptadine, and mianserin.

These early studies were the first attempts to identify the distribution and pharmacological properties of diverse 5-HT receptors in Aplysia. They demonstrated the presence of 5-HT receptors in virtually all Aplysia tissue types and especially in the CNS. They also suggested the existence of at least six receptor subtypes. The development of molecular biological techniques and the possibility of cloning and expressing individual 5-HT receptor subtypes in cell lines allowed further elucidation of the electrophysiological and pharmacological properties of the serotonergic pathways in Aplysia.

\section{Structural and Pharmacological Characterizations and Tissue Distribution of Cloned 5-HT Receptors}

\section{Cloning of 5-HT Receptors in Aplysia}

Four 5-HT receptors have been characterized in Aplysia to date. $\mathrm{Li}$ et al. (1995) isolated potential genes that encode Aplysia 5-HT receptors by performing a PCR analysis of Aplysia genomic DNA. In order to amplify potential 5-HT receptors, they used degenerate PCR primers whose sequences were based on conserved peptide sequences found in the sixth and the seventh transmembrane domains of all known serotonergic GPCRs. Two different genomic clones, $A p 5-H T_{B 1}$ and $A p 5-H T_{B 2}$, were isolated. The $A p 5$ $H T_{B 1}$ gene codes for a protein of 453 amino acids (GenBank accession no. L43557) containing seven hydrophobic putative transmembrane domains, a relatively short third intracellular loop, and a long C-terminal tail. Genomic analysis further demonstrates that the gene is intronless. The $A p 5-H T_{B 2}$ gene is also intronless and codes for a closely related protein of 422 aa (GenBank accession no. L43558) which shares 90\% amino acid sequence identity with the $\mathrm{Ap} 5-\mathrm{HT}_{\mathrm{B} 1}$ within the transmembrane domains and adjacent regions. The N-terminal extracellular domain and the extracellular loops I and II are less conserved. More divergence occurs within the third intracellular loop and the Cterminal tail. It is possible that other related receptors are present in the Aplysia genome, because a Southern blot analysis of genomic DNA, probed with the coding region of $\mathrm{Ap} 5-\mathrm{HT}_{\mathrm{B} 1}$, revealed five distinct bands. Dendrogram analysis of the amino acid sequences of cloned 5-HT receptors indicated that Ap5-HT and $\mathrm{Ap} 5-\mathrm{HT}_{\mathrm{B} 2}$ are only distantly related to the rest of the known 5-HT receptors (Fig. 2). They could not be readily grouped within any of the mammalian subgroups based on amino acid sequence identity.

A third 5-HT receptor gene was cloned and characterized from Aplysia and named 5-HT ${ }_{a p 1}$ (Angers et al. 1998). Degenerate primers and PCR amplification were used to screen CNS and kidney cDNA libraries. A cDNA coding for a putative protein of 492 aa containing seven stretches of hydrophobic residues, a relatively large third cytoplasmic loop, and a short C-terminal tail, features common to several $5-\mathrm{HT}_{1}$ receptors, was isolated (GenBank accession no. AF041039; Boess and Martin 1994; Gerhardt and van Heerikhuizen 1997). Southern blot analysis of genomic DNA revealed that the $5-H T_{a p 1}$ gene is probably intronless and does not have a close homolog in the Aplysia genome. Dendrogram analysis of amino acid sequence within the transmembrane domains also suggests that $5-H T_{a p 1}$ is associated with the mammalian $5-\mathrm{HT}_{1}$ receptor family (Fig. 2).

The same cloning strategy was used to obtain the sequence



Figure 2 Dendrogram analysis of different members of the 5-HT receptor superfamily. Sequences that were used for phylogenetic analysis were retrieved from the GenBank database. The sequences of serotonin receptors were compared and aligned using ClustalW (Thompson et al. 1994), which was executed from GDE (Genetic Data Environment; J. Felsenstein 1993, PHYLIP, Phylogeny Inference Package, version 3.5.1C and 3.6, University of Washington, Seattle, WA). Only amino acid positions that could be aligned without ambiguity were used for the analysis. The alignment was then used for phylogenetic comparisons using the PHYLIP package. Analysis was performed with a bootstrap procedure that computes the probability of occurrence of the branches for 1000 possible trees. Branching order was determined using the Fitch-Margoliash algorithm included in the PHYLIP package. Only branches occurring in $>800$ trees are represented. DRO, Drosophila; FUG, Fugu rubripes (pufferfish); LYM, Lymnaea; HUM, human; MUS, mouse.

of a fourth Aplysia 5-HT receptor gene, named 5- $H T_{a p 2}$ (GenBank accession no. AF372526; Barbas et al. 2002). The cDNA contains an open reading frame encoding a protein of 567 aa with a predicted molecular mass of $63 \mathrm{kD}$. Hydrophobicity analysis reveals the presence of the seven transmembrane domains characteristic of GPCRs. Its large third cytoplasmic loop, its short C-terminal tail, and the observation that the $5-\mathrm{HT}_{a p 2}$ gene is probably intronless and does not have a close homolog in the Aplysia genome are reminiscent of members of the vertebrate $5-\mathrm{HT}_{1}$ receptor family and similar to the 5- $\mathrm{HT}_{1}$-like Aplysia receptor 5- $\mathrm{HT}_{\mathrm{ap} 1}$. Amino acid sequence comparisons between the $5-\mathrm{HT}_{\mathrm{ap} 2}$ receptor and other 5-HT receptors show significant sequence identity to the $5-\mathrm{HT}_{1}$-like receptors, and a dendrogram analysis places $5-\mathrm{HT}_{\mathrm{ap} 2}$ within the family of mammalian $5-\mathrm{HT}_{1}$ receptors (Fig. 2). Sequence analysis also reveals that $5-\mathrm{HT}_{\mathrm{ap} 2}$ has close amino acid identity (68\%) with the Lymnaea stagnalis 5-HT receptor 5- $\mathrm{HT}_{\mathrm{lym}}$ (Sugamori et al. 1993), suggesting that they may be orthologous.

\section{Ap5- $H T_{B 1}$ and $A p 5-H T_{B 2}$ Receptors Activate Phospholipase $C$ and Have Different Expression Patterns}

To identify their pharmacological profiles, Ap5-HT $\mathrm{B}_{\mathrm{B} 1}$ and Ap5$\mathrm{HT}_{\mathrm{B} 2}$ receptors were stably expressed in HEK 293 cells (Li et al. 1995). In response to 5-HT, both receptors stimulate phospholipase $\mathrm{C}$ activity, reaching a plateau at $100 \mathrm{nM}$. Therefore, the stimulation of these two receptors might lead to the activation of PKC. The estimated $\mathrm{EC}_{50}$ for $5-\mathrm{HT}$ was $1.8 \mathrm{nM}$ for $\mathrm{Ap} 5-\mathrm{HT}_{\mathrm{B} 1}$ and $1.5 \mathrm{nM}$ for $\mathrm{Ap} 5-\mathrm{HT}_{\mathrm{B} 2}$. Methiothepin and spiperone, which are respectively nonselective $5-\mathrm{HT}$ and $5-\mathrm{HT}_{2 \mathrm{~A} / 1}$ antagonists, both prevent the 5-HT-dependent stimulation of phospholipase $\mathrm{C}$ at $10 \mu \mathrm{M}$ concentration. However, cyproheptadine $(10 \mu \mathrm{M})$, another 5-HT $\mathrm{H}_{1-2}$ antagonist, has no effect. Thus, although Ap5-HT and $\mathrm{Ap} 5-\mathrm{HT}_{\mathrm{B} 2}$ do not appear to be the invertebrate homologs of 
the mammalian $5-\mathrm{HT}_{2}$ receptors, they do have similar coupling to phospholipase $\mathrm{C}$.

RT-PCR experiments on mRNA isolated from various tissues of Aplysia showed that Ap5- $\mathrm{HT}_{\mathrm{B} 1}$ mRNA is expressed in spermatheca and ovotestis, whereas $\mathrm{Ap} 5-\mathrm{HT}_{\mathrm{B} 2}$ mRNA is detected only in the CNS. As Ap5- $\mathrm{HT}_{\mathrm{B} 1}$ and $\mathrm{Ap} 5-\mathrm{HT}_{\mathrm{B} 2}$ have similar pharmacological profiles but different expression patterns, Li et al. (1995) suggested that these two receptors might result from the recent duplication of an ancestral gene, which placed the coding sequence of the ancestral gene under the control of totally different promoter sequences.

\section{The 5-HT $T_{a p l}$ Receptor Is Negatively Coupled to Adenylyl Cyclase}

The pharmacological profile and expression pattern of the $5-\mathrm{HT}_{\mathrm{ap} 1}$ receptor were also characterized (Angers et al. 1998). This receptor, fused to a c-myc epitope at its $\mathrm{N}$ terminus, was expressed in mammalian HEK 293 cells. Isolated membranes bind $\left[{ }^{3} \mathrm{H}\right] \mathrm{LSD}$ in a saturable and dose-dependent manner with an estimated $K_{d}$ of $0.56 \mathrm{nM}$. The rank order of potency of various serotonergic agonists and antagonists for inhibition of $\left[{ }^{3} \mathrm{H}\right] \mathrm{LSD}$ binding is given in Table $1.5-\mathrm{HT}_{\mathrm{ap} 1}$ shows high-affinity binding to 5-HT which is comparable to that of the mammalian 5- $\mathrm{HT}_{1 \mathrm{~A}, \mathrm{~B}, \mathrm{D}, \mathrm{F}}$, and 5- $\mathrm{HT}_{7}$ receptors. From these results, Angers et al. (1998) concluded that the pharmacological profile of $5-\mathrm{HT}_{\mathrm{ap} 1}$ seems to be related to the mammalian $5-\mathrm{HT}_{1}$ and $5-\mathrm{HT}_{7}$ receptor profiles. The structure and function of the $5-\mathrm{HT}_{\mathrm{ap} 1}$ receptor are probably closely related to those of an ancestral receptor, which existed before the divergence of the 5-HT receptor subtypes in vertebrates. It appears to have kept the characteristics of more than one receptor subtype, possibly related to a prototype of the early $5-\mathrm{HT}_{1,7}$ receptors.

As expected from the structure and pharmacological profile of 5 - $\mathrm{HT}_{\mathrm{ap} 1}$, stimulation of the receptor with 5-HT in HEK 293 cells inhibits forskolin-induced cAMP accumulation in a dosedependent manner (Angers et al. 1998). This inhibition is blocked in the presence of $100 \mathrm{nM}$ of the antagonist methiothepin. These experiments indicate that $5-\mathrm{HT}_{\mathrm{ap} 1}$ is functionally coupled to the mammalian Gi subunit and inhibits adenylyl cyclase and cAMP accumulation (Angers et al. 1998).

Table 1. Comparison of the Affinities of Various Compounds That Compete With the Binding of $\left[{ }^{3} \mathrm{H}\right]$ LSD to the Membranes of Cells Transfected With the $5-\mathrm{HT}_{\mathrm{ap} 1}$ and $5 \mathrm{HT}_{\mathrm{ap} 2} \mathrm{CDNA}$

\begin{tabular}{|c|c|c|c|}
\hline \multirow[b]{2}{*}{ Drug } & \multirow[b]{2}{*}{ Specificity } & \multicolumn{2}{|c|}{$\mathrm{K}_{\mathrm{i}}(\mathrm{nM})$} \\
\hline & & $5-\mathrm{HT}_{\mathrm{ap1}}{ }^{\mathrm{a}}$ & $5-\mathrm{HT}_{\mathrm{ap} 2}{ }^{\mathrm{b}}$ \\
\hline $5-\mathrm{CT}$ & 5- $\mathrm{HT}_{1}$ agonist & 1.04 & 162 \\
\hline Methiothepin & $\begin{array}{l}\text { Nonselective } 5-\mathrm{HT} \\
\text { antagonist }\end{array}$ & 2.62 & 0.3 \\
\hline PAPP & $\begin{array}{l}\text { 5- } \mathrm{HT}_{1 \mathrm{~A}} \\
\text { agonist/5- } \mathrm{HT}_{1 \mathrm{D}} \\
\text { antagonist }\end{array}$ & 9.50 & 182 \\
\hline $5-\mathrm{HT}$ & & 13.23 & 241 \\
\hline Clozapine & $5-\mathrm{HT}_{2}$ antagonist & 56.63 & 2124 \\
\hline 8-OH-DPAT & $\begin{array}{l}5-\mathrm{HT}_{1 \mathrm{~A}} \text {-specific } \\
\text { agonist }\end{array}$ & 73.96 & 2089 \\
\hline Metergoline & $5-\mathrm{HT}_{1-2-7}$ antagonist & 90.66 & 36 \\
\hline Ketanserin & $5-\mathrm{HT}_{2}$ antagonist & 288.18 & 561 \\
\hline NAN-190 & $\begin{array}{c}5 \text {-HT }_{1 \mathrm{~A}} \text {-specific } \\
\text { antagonist }\end{array}$ & $>1000$ & 1030 \\
\hline Dopamine & & $>1000$ & $>10,000$ \\
\hline
\end{tabular}

Affinity estimates are given as $\mathrm{K}_{\mathrm{i}}$ values in nanomolar concentrations and were determined by a computer-assisted nonlinear curve analysis (GraphPad PRISM 3.0 computer program). ${ }^{2}$ Adapted from Angers et al. (1998); badapted from Barbas et al. (2002).
To determine the distribution of $5-\mathrm{HT}_{\mathrm{ap} 1}$ protein, Angers et al. (1998) performed a Western blot analysis of plasma membrane extracts and RT-PCR amplification of mRNA isolated from various Aplysia tissues and found that both the protein and mRNA could be detected in the gill, heart, hermaphroditic duct, kidney, and ovotestis extracts. It is also present in all ganglia of the CNS (Angers et al. 1998). Because 5- $\mathrm{HT}_{\mathrm{ap} 1}$ is present in most Aplysia tissue membranes, this receptor might play a role in multiple physiological functions of 5-HT such as reproduction, circadian rhythms, feeding, and modulation of defensive behavior.

\section{The 5-HT $T_{\text {ap2 }}$ Receptor Is Negatively Coupled to Adenylyl Cyclase and Is Exclusively Expressed in the CNS}

Membranes isolated from transiently transfected HEK 293 cells with $5-\mathrm{HT}_{\mathrm{ap} 2}$ receptor bind $\left[{ }^{3} \mathrm{H}\right] \mathrm{LSD}$ in a saturable and dose-dependent manner with an estimated $\mathrm{K}_{\mathrm{d}}$ of $4.37 \mathrm{nM}$ (Barbas et al. 2002). The rank order of affinity of various serotonergic agonist and antagonists is given in Table 1 . As expected for a 5-HT receptor, 5- $\mathrm{HT}_{\mathrm{ap} 2}$ displayed a higher affinity for 5-HT than for dopamine or octopamine. Its pharmacological profile revealed important differences when compared to those of the mammalian members of the 5-HT 1 subfamily. Methiothepin, a nonselective 5-HT antagonist, showed the strongest affinity (Table 1 ). The affinity of $5-\mathrm{HT}_{\mathrm{ap} 2}$ for methiothepin is higher than for any of the cloned mammalian 5-HT receptors. These results suggest that the functions of 5- $\mathrm{HT}_{\mathrm{ap} 2}$ receptor are probably related to those of an ancestral receptor, which existed before the divergence of the 5-HT receptor subtypes in vertebrates, and that it kept characteristics of more than one receptor subtype (5- $\mathrm{HT}_{1,5,7}$ receptors). The pharmacological profile of $5-\mathrm{HT}_{\mathrm{ap} 2}$ is distinct from that of $5-\mathrm{HT}_{\mathrm{ap} 1}$ (Table 1). It will now be possible to discriminate between these $5 \mathrm{HT}_{1}$-like receptors in 5-HT-induced physiological responses using appropriate agonists and/or antagonists.

Stimulation of the 5- $\mathrm{HT}_{\mathrm{ap} 2}$ receptor by 5-HT in HEK 293 cells inhibits forskolin-induced cAMP accumulation in a dose-dependent manner (Barbas et al. 2002). The same result was obtained with the agonist 5-CT. In addition, 5-HT produces no inhibition of cAMP accumulation in the presence of $1 \mathrm{nM}$ of the antagonist methiothepin. Pertussis toxin, a known Gi-protein inhibitor, at a concentration of $50 \mathrm{ng} / \mathrm{mL}$, completely blocks the effect of $5-\mathrm{HT}$, indicating that $5-\mathrm{HT}_{\mathrm{ap} 2}$ receptor interacts with a pertussis toxinsensitive G-protein. Interestingly, treatment with pertussis toxin not only inhibits the Gi-dependent decrease of cAMP level, but also seems to reveal a functional coupling between $5-\mathrm{HT}_{\mathrm{ap} 2}$ and Gs-protein that produces an increase in the cAMP level. Examples of such dual coupling to Gs and Gi pathways have been reported for the $\alpha_{2 A^{-}}$and $\beta_{2}$-adrenergic receptors in mammalian cells (Eason and Liggett 1995; Xiao et al. 1995). Stimulation of the $5-\mathrm{HT}_{\mathrm{ap} 2}$ receptor can modulate overlapping but distinct sets of signal transduction mechanisms by its interaction with Gi and Gs.

The expression of 5- $\mathrm{HT}_{\mathrm{ap} 2}$ mRNA in various tissues of Aplysia was screened by RT-PCR and was found only in the CNS. 5- $\mathrm{HT}_{\mathrm{ap} 2}$ mRNA could be detected in the abdominal ganglion (without the bag cells), in the bag cells, and also weakly in the cerebral and pleural-pedal ganglia (Barbas et al. 2002). The finding that its expression is restricted to the CNS suggests a potential role for the $5-\mathrm{HT}_{\mathrm{ap} 2}$ receptor in modulating synaptic transmission and neuronal excitability.

\section{5-HT Receptor(s) Coupled to Gs or 5-HT $T_{a p A C}$}

5-HT receptors that activate adenylyl cyclase, or Gs-coupled receptors, have not yet been cloned in Aplysia. One hypothesis would be that, although one or several specific Gs-coupled 5-HT receptors might be expressed in the CNS, the amount of mRNA coding for these receptors is lower than that coding for receptors 
that have already been cloned. Therefore the techniques used to preferentially amplify the most abundant cDNA might not be an effective strategy. PCR amplification of SN libraries would help resolve this problem. Another hypothesis would be that the Gi or Gq 5-HT receptors also fulfill coupling to Gs under different conditions of stimulation by 5 -HT. This possibility seems unlikely, however, because Cohen et al. (2003) found distinct pharmacological properties for an adenylyl cyclase-coupled 5-HT receptor.

Cohen et al. (2003) recently used biochemical assays to pharmacologically characterize the 5-HT receptor(s) that activates adenylyl cyclase in the Aplysia CNS. They also examined the 5-HT-induced cAMP-dependent modulation of the electrophysiological properties of SNs. They identified compounds that are effective in blocking the Gs-coupled 5-HT receptor(s) in Aplysia CNS and called this class of receptor 5- $\mathrm{HT}_{\mathrm{apAC}}$. Eight of the 14 tested antagonists were effective against $5-\mathrm{HT}_{\mathrm{apAC}}$ in CNS membranes. The rank order of potency of these antagonists is given in Table 2, with methiothepin being the antagonist with the highest potency. Comparison of the pharmacological profile of the $5-\mathrm{HT}_{\text {apAC }}$ receptor with those of mammalian 5-HT receptor subtypes suggests that it most closely resembles the $5-\mathrm{HT}_{6}$ receptor subtype, although two specific $5-\mathrm{HT}_{6}$ antagonists (olanzapine and Ro-04-6790) were not effective against 5-HT $\mathrm{HpAC}_{\text {. }}$

Of the 14 compounds tested, methiothepin was also the most effective in inhibiting 5-HT stimulation of adenylyl cyclase. Methiothepin substantially inhibited two effects of 5-HT on SN firing properties: spike broadening in tetraethylammonium/nifedipine and increased excitability. Consistent with cyproheptadine blocking 5-HT stimulation of adenylyl cyclase, cyproheptadine also blocked the 5-HT-induced increase in SN excitability. In conjunction with other pharmacological probes, Cohen et al. (2003) proposed that the antagonist methiothepin should be useful in analyzing the role of 5-HT in various forms of neuromodulation in Aplysia.

Thus far, none of these four cloned Aplysia 5-HT receptors have been formally implicated in the molecular processes underlying synaptic facilitation or memory encoding. However, because we know the G-proteins that are potentially coupled to these receptors, the wealth of information on biochemical cascades activated by G-proteins in this and other systems can now help us infer their possible roles in sensitization. These possibilities will now be discussed.

Table 2. Antagonists Tested for Inhibition of 5-HT Stimulation of Adenylate Cyclase in Aplysia CNS

\begin{tabular}{ll}
\hline Antagonists $^{\mathrm{a}}$ & \multicolumn{1}{c}{ Specificity } \\
\hline Methiothepin & Nonselective $5-\mathrm{HT}$ antagonist \\
Metergoline & $5-\mathrm{HT}_{1-2-7}$ antagonist \\
Fluphenazine & $\mathrm{D}_{1} / \mathrm{D}_{2}$ dopamine receptor antagonist \\
Clozapine & $5-\mathrm{HT}_{2}$ antagonist \\
Cyproheptadine & $5-\mathrm{HT}_{1-2}$ antagonist \\
Risperidone & $5-\mathrm{HT}_{2}$ antagonist/ ${ }_{2}$ dopamine receptor \\
& antagonist \\
Ritanserin & $5-\mathrm{HT}_{2 \mathrm{~A}}$ antagonist/inverse agonist \\
NAN-190 & Selective 5- $\mathrm{HT}_{1 \mathrm{~A}}$ antagonist \\
Inactive antagonists & \\
GR-113808 & Selective 5- $\mathrm{HT}_{4}$ antagonist \\
SB-204070 & Selective $5-\mathrm{HT}_{4}$ antagonist \\
Olanzapine & $5-\mathrm{HT}_{2-6}$ antagonist \\
Ro-04-6790 & Selective $5-\mathrm{HT}_{6}$ antagonist \\
RS-102221 & Selective $5-\mathrm{HT}_{2 \mathrm{C}}$ antagonist \\
Spiperone & $5-\mathrm{HT}_{2 \mathrm{~A} / 1}$ antagonist/D \\
& antagonist $_{2}$ dopamine receptor \\
&
\end{tabular}

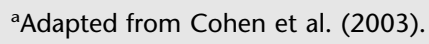

\section{Possible Physiological Roles of Aplysia 5-HT Receptors}

\section{Activation of 5-HT Gs-coupled Receptor(s)}

The modulatory effects of activation of a potential 5-HT Gscoupled receptor in the Aplysia nervous system have been studied in considerable detail. Following binding of 5-HT, these receptors activate adenylyl cyclase (AC) and increase the concentration of cAMP in SNs (Fig. 3). In turn, cAMP activates PKA by causing its two regulatory subunits to dissociate from the catalytic subunits, which then phosphorylate and covalently modify a number of target proteins (Ghirardi et al. 1992; Braha et al. 1993; Byrne and Kandel 1996; Angers et al. 2002a). The switch from short- and intermediate-term to long-term synaptic facilitation is initiated by multiple exposures to 5-HT, which induce PKA to translocate to the nucleus where it stimulates gene transcription. There, PKA is thought to lead to removal of the inhibitory action of the repressor cyclic AMP response element binding protein-2 (CREB2 ). Some of these nuclear PKA effects could rely on its ability to recruit ERK, which is also translocated to the nucleus, where it is thought to phosphorylate CREB-2 and contribute to the activation of a transcriptional cascade. PKA phosphorylation of a transcriptional activator cyclic AMP response element binding protein-1 (CREB-1) is necessary for its binding to cyclic AMP regulatory elements (CREs), located in the promoter region of cAMP-inducible genes (for review, see Alberini 1999). Because binding of 5-HT to a receptor that engages a G-protein increasing the activity of $\mathrm{AC}(\mathrm{Gs})$ is the initial step in this cascade of molecular events, cloning of the $5-\mathrm{HT}_{\mathrm{apAC}}$ receptor(s) would give us important information about the molecular mechanisms underlying synaptic facilitation. Expression of these receptors in cell lines would then help identify their functional properties and their possible mechanisms of regulation (binding, time of expression to the membranes, desensitization of the receptor, cross-talk with other pathways, heterodimerization, etc.). It could also allow the synthesis of specific drugs or antibodies capable of blocking their action during sensitization training.

\section{Activation of Two 5-HT Gi-coupled Receptors}

Application of 5-HT has generally been associated with an increase in cAMP levels in Aplysia. Nevertheless, application of 5-HT also triggers inhibitory responses in Aplysia (Jennings et al. 1981; Frost et al. 1988; Fisher and Carew 1993; Ram et al. 1994; $\mathrm{Xu}$ et al. 1995; Storozhuk and Castellucci 1999a,b; Bristol et al. 2001). In these cases, binding of 5-HT to Gi-coupled 5-HT receptors in the CNS could be involved. Gi-coupled 5-HT receptors can interfere, by their negative coupling to AC, with pathways that are dependent on cAMP. They might also be involved in modulating PKC or ERK pathways, perhaps by cross-talk between receptors. This phenomenon could be implicated in behavioral plasticity and learning in Aplysia.

5-HT receptors that inhibit AC have been implicated in learning and memory processes in mammals: Depending on their cellular localization, they can act by inhibiting the firing rate and/or by decreasing neurotransmitter release (Buhot et al. 1995; Buhot 1997). In mammalian systems, a subset of 5 - $\mathrm{HT}_{1 \mathrm{~A}}$ receptors, the somatodendritic autoreceptors, reduce cell firing and curtail the synthesis and release of 5-HT (Buhot 1997). Activation of serotonergic autoreceptors in the presynaptic nerve terminal $\left(5-\mathrm{HT}_{1 \mathrm{D}}\right.$ receptors in human or $5-\mathrm{HT}_{1 \mathrm{~B}}$ receptors in rodents) decreases the local synthesis and release of transmitter (Buhot et al. 1995). Further investigation of the detailed localization of the $5-\mathrm{HT}_{\mathrm{ap} 1}$ and 5- $\mathrm{HT}_{\mathrm{ap} 2}$ receptors in the Aplysia CNS is necessary to determine whether these receptors are also autoreceptors. Identification of the expression patterns at the cellular and subcellular levels should provide additional clues about their role in the modulation of synaptic transmission that occurs dur- 


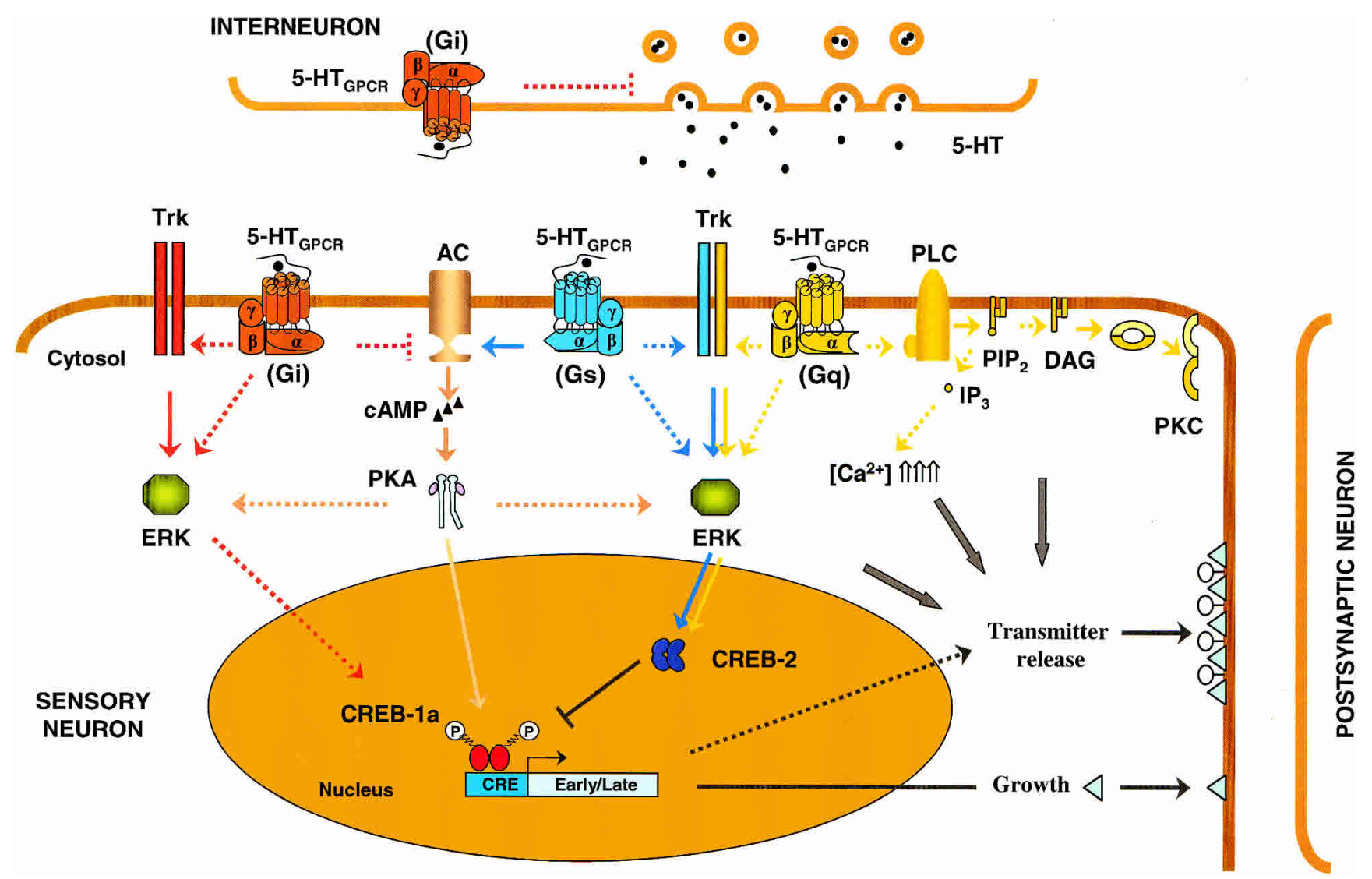

Figure 3 Schematic representation of putative roles of 5-HT receptor modulation of neuronal properties in Aplysia californica. The sensory neuron to motor neuron synapse involved in withdrawal reflexes is used as an example. After stimulation, facilitatory serotonergic interneurons release 5 -HT that binds $5-\mathrm{HT}$ receptors $\left(5-\mathrm{HT}_{\mathrm{GPCR}}\right.$ ). The final effect of 5-HT may depend on the specific expression patterns of 5-HT receptors and signaling molecules within different cells. Binding of 5-HT to a Gs-coupled receptor stimulates adenylyl cyclase (AC; pink pathway). Activation of the cyclase increases the cAMP concentration and induces activation of the cyclic AMP-dependent protein kinase A (PKA; activation is indicated by an arrow). Activation of PKA can phosphorylate and covalently modify a number of target proteins, including components of the exocytotic machinery of release, to enhance transmitter availability and release. With repeated stimulation, PKA can recruit the extracellular signal-regulated kinase (ERK, MAPK), and can translocate to the nucleus where it phosphorylates the cyclic AMP response element binding proteins (CREBs). Phosphorylation by ERK of the repressor isoform CREB-2 removes its inhibition on CREB-1a. Phosphorylation of CREB-1a induces transcription of early/late genes containing cyclic AMP response elements, leading to growth of new synaptic connections and potentially transmitter release. Gs-coupled receptor might also activate ERK (blue pathway) by transactivation of receptor tyrosine kinases (e.g., Trk, which can be activated by neurotrophins), or by direct activation of the ERK cascade. To turn down the release of 5-HT from interneurons, Gi-coupled receptors might act as presynaptic autoreceptors (inhibition is indicated by - ). When expressed at the surface of sensory neurons, Gi-coupled receptors can inhibit the Gs-dependent activation of the cyclase and turn down the cascade (red pathway). Under sustained release of 5-HT, Gi-coupled receptors might complement the activation of the ERK pathway by transactivation of Trks or direct activation of ERK components. Besides the PKA-signal pathway, there is a phospholipase C-PKC signaling pathway activated by 5-HT receptors (beige pathway). Gq-coupled receptor-activated phospholipase C (PLC) produces diacylglycerol (DAG) and inositol triphosphate (IP $)_{3}$ by cleaving the phosphatidyl inositol PIP ${ }_{2}$. IP $P_{3}$ is water-soluble, and can diffuse into the cytoplasm. There it binds to a receptor on the endoplasmic reticulum to release $\mathrm{Ca}^{2+}$ from internal stores. DAG remains in the membrane, where it activates the protein kinase C (PKC). Gq-coupled receptors might also be capable of enhancing the activation of the ERKs. For clarity only, two different sets of Trk receptors and ERK appear on the figure; there is no evidence that Gi-, Gs-, or Gq-activated pathways modulate distinct pools of ERK. Transmitter availability and release can also be dependent on activation of other signaling molecules (e.g., PKC, $\mathrm{Ca}^{2+}$ ) as shown by gray arrows. Speculative interactions are represented by ( - - ). The molecular mechanisms underlying serotonergic modulation of MNs are still poorly understood and were omitted on this diagram.

ing learning and memory. Although, in principle, Gs- or Gqcoupled 5-HT receptors could also decrease transmitter release in Aplysia, data from mammalian systems suggest that $5-\mathrm{HT}_{\mathrm{ap} 1}$ and $5-\mathrm{HT}_{\mathrm{ap} 2}$ are more likely to be involved in these inhibitory actions, either in serotonergic neurons, where they would act as autoreceptors, or in interneurons, where they could be implicated in the inhibitory action of 5-HT in polysynaptic pathways (Trudeau and Castellucci 1992, 1993).

\section{Activation of Gq-coupled Receptors}

Besides the PKA-signaling pathway, a phospholipase C-PKC-signaling pathway can also be activated by 5 -HT receptors. Binding of 5-HT to Gq-coupled receptors activates phospholipase C
(PLC). PLC then cleaves phosphatidyl inositol $\mathrm{PIP}_{2}$ to produce diacylglycerol (DAG) and inositol triphosphate $\left(\mathrm{IP}_{3}\right)$. $\mathrm{IP}_{3}$ is watersoluble and diffuses into the cytoplasm, where it binds to a receptor on the endoplasmic reticulum to release $\mathrm{Ca}^{2+}$ from internal stores. DAG remains in the membrane where it activates PKC, which is active only when translocated from the cytoplasm to the membrane. Binding of 5-HT to Gq-coupled receptor(s) can activate a $\mathrm{Ca}^{2+}$-dependent PKC in SNs of Aplysia (Fig. 3; Sacktor and Schwartz 1990; Sossin and Schwartz 1992). There is no evidence of 5-HT-mediated $\mathrm{IP}_{3}$ production or release of $\mathrm{Ca}^{2+}$ from internal stores in sensory neurons after activation of 5-HT receptors. Interestingly, Manseau et al. (2001) demonstrated that the $\mathrm{Ca}^{2+}$-independent form of PKC is very important for facilitation 
at depressed synapses. The link between a 5-HT Gq-coupled receptor and the activation of the $\mathrm{Ca}^{2+}$-independent form of $\mathrm{PKC}$ is unclear. Because PKC activity contributes to facilitation of neurotransmitter release, modulates $\mathrm{K}^{+}$currents, and contributes to spike broadening, the $\mathrm{Ap} 5-\mathrm{HT}_{\mathrm{B} 2}$ receptor might therefore be involved in modulation of synaptic plasticity (Ghirardi et al. 1992; Sossin et al. 1994; Sugita et al. 1994).

\section{G-protein Regulation of Ion Channels}

Many types of neurotransmitter receptors regulate ion channels through activation of G-proteins. The process by which this regulation occurs is best established for Gi-coupled receptors. The $5-\mathrm{HT}_{1 \mathrm{~A}}$ receptors, when coupled to G-protein, activate specific inwardly rectifying $\mathrm{K}^{+}$channels in mammalian neurons (Ehrengruber et al. 1997), or inhibit voltage-gated $\mathrm{Ca}^{2+}$ channels (Lembo et al. 1997). Regulation of both types of channel most likely occurs primarily through the $\beta \gamma$ subunits of G-proteins, which directly open the $\mathrm{K}^{+}$channels and limit the opening of $\mathrm{Ca}^{2+}$ channels in response to membrane depolarization (Mark and Herlitze 2000; Zamponi 2001). Some evidence also suggests

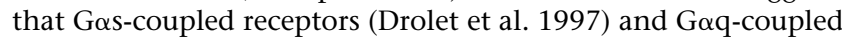
receptors (Simen et al. 2001; Zamponi 2001) modulate the voltage-dependent gating of certain $\mathrm{Ca}^{2+}$ channels. In Aplysia, 5-HT modulates $\mathrm{K}^{+}$and $\mathrm{Ca}^{2+}$ channel responses (Klein and Kandel 1980; Siegelbaum et al. 1982; Benson and Levitan 1983; Shuster et al. 1991; Braha et al. 1993; Sugita et al. 1994). This regulation is thought to rely on the activation of PKA and/or PKC pathways. However, it is also possible that direct modulation of ion channels by 5-HT receptors, independently from the activation of downstream messenger cascades, might be involved in the regulation of synaptic transmission that occurs during behavioral modifications in Aplysia.

\section{Cross-Talk Between 5-HT Receptors in Aplysia}

GPCRs have long been viewed as acting through parallel biochemical pathways. However, a growing amount of evidence now suggests that these pathways are not always independent and that significant interactions can occur between receptors or G-proteins. This phenomenon is usually referred to as "cross-talk."

In Aplysia, ERK, a downstream substrate of many tyrosine kinase signaling cascades, has been implicated in the induction of long-term synaptic plasticity (Martin et al. 1997; Zhang et al. 1997). Purcell et al. (2003) recently demonstrated that tyrosine kinase activity is required for both 5-HT-induced long-term synaptic facilitation of $\mathrm{SN}-\mathrm{MN}$ synapses and tail-shock-induced long-term sensitization. Moreover, both effects of tyrosine kinase activity are mediated, at least in part, through ERK activation. Most importantly, these results suggest that tyrosine kinase activation occurs downstream of the 5-HT receptor, but upstream of ERK activation (Fig. 3). A variety of biochemical mechanisms through which GPCRs activate ERK have been demonstrated (for review, see Lowes et al. 2002; Luttrell 2002). Potential mechanisms for ERK activation are signals initiated by classical G-protein effectors leading to a PKA- and/or PKC-dependent phosphorylation of proteins involved in ERK activation. GPCRs can potentially activate ERK via cAMP (Stork and Schmitt 2002) and DAG (Puente et al. 2000) via a PKA- and/or PKC-independent mechanism. Activation of ERK has typically been attributed to the activation of receptor tyrosine kinase (RTK) in neurons, for example by the epidermal growth factor (EGF) receptors, by the nerve growth factor (NGF) receptors, or by Trk receptors which are activated by neurotrophins (Lowes et al. 2002). Originally, activation of GPCRs and RTKs by extracellular messages was thought to occur independently. Increasing evidence demonstrates that there are complex interactions between each of these pathways. At least two RTKs, platelet-derived growth factor
(PDGF) receptors (Linseman et al. 1995; Herrlich et al. 1998) and EGF receptors (Luttrell et al. 1997; Eguchi et al. 1998) can be "transactivated" by GPCRs. Cross-talk between GPCRs and RTKs allows integration of extracellular signals on the ERK cascade. For example, many GPCR agonists have been shown to trigger activation of the ERK cascade through tyrosine phosphorylation of RTKs, leading to a transactivation of these receptors. Direct interaction between $\beta$-arrestin and components of the ERK cascade might also be involved in ERK activation (for review, see Lowes et al. 2002; Luttrell 2002). The contribution of various $G \alpha$ (Gos,

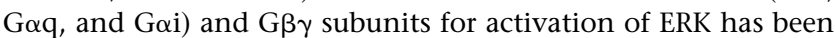
reviewed by Gutkind (1998). It is now apparent that GPCRs can activate ERK via intracellular intermediates such as calcium, PKC, cAMP, PKA, phosphatidylinositol 3-kinase (PI3K), or via G $\alpha$ and $\mathrm{G} \beta \gamma$ subunits. It is attractive to think that one way of strengthening the induction and maintenance of memory in Aplysia might be through the activation of diverse 5 -HT receptors that modulate the ERK pathway, which is involved in the induction of transcription (Fig. 3). One can then imagine a situation where robust stimulation would cause a large release of 5-HT, which would bind to Gi-, Gq-, and Gs-coupled receptors. Activation of these receptors would activate several signaling cascades that would converge on ERK, an essential step for the induction of long-term synaptic plasticity.

The two protein kinase cascades activated by 5-HT, PKA and PKC, are also capable of interacting in Aplysia (Byrne and Kandel 1996). For example, Sugita et al. (1997) showed that activation of PKC by phorbol esters specifically attenuated aspects of the 5-HT activation of the cAMP/PKA cascade. Previous studies have demonstrated that PKC interacts with a cAMP/PKA cascade at the level of AC by increasing its activity and consequently the level of cAMP (for review, see Pieroni et al. 1993; Cooper et al. 1995). PKC can also interact with the PKA cascade at the level of the receptor. PKC can phosphorylate various types of receptors bound to ligands, resulting in desensitization and inhibition of the ligand-induced increases in intracellular messengers in mammals (Zhang et al. 1996; Dale et al. 2002). In Aplysia neurons, 5-HT binding to Gq- and Gs-coupled receptors could mediate PKC inhibition of 5-HT-induced activation of the PKA pathway, thereby leading to the suppression of 5-HT-induced facilitation at the transition between short- and long-term memory (Sugita et al. 1997). This mechanism would explain why synaptic facilitation induced by long 5-HT exposure requires PKC, whereas short 5-HT pulses necessitate PKA (Braha et al. 1990; Hochner and Kandel 1992; Sugita et al. 1992).

Cross-talk can also occur at the level of the receptors. It was demonstrated that phosphorylation by PKA of some GPCRs switches the coupling of the $\beta_{2}$ adrenoreceptor from Gs to Gi (Daaka et al. 1997; Zamah et al. 2002). Barbas et al. (2002) showed that treatment with pertussis toxin not only inhibits a Gi-dependent decrease of cAMP level by the $5-\mathrm{HT}_{\mathrm{ap} 2}$ receptor, but also seems to reveal a functional coupling between $5-\mathrm{HT}_{\mathrm{ap} 2}$ and Gs-protein that produces an increase in the cAMP level. These findings indicate that stimulation of $5-\mathrm{HT}_{\mathrm{ap} 2}$ can modulate overlapping but distinct sets of signal transduction mechanisms, and can give rise to distinct (or even opposing) physiological functions in Aplysia neurons by its dual coupling properties. Thus, $5-\mathrm{HT}_{\mathrm{ap} 2}$ might be capable of complementing the activation of $5-\mathrm{HT}_{\mathrm{apAC}}$ receptors in modulating short-term and long-term memory.

The discovery that GPCRs may form heterodimers that display distinct pharmacological properties raises fascinating possibilities concerning the plasticity and diversity of these signaling systems (for review, see Bouvier 2001; Angers et al. 2002b). 5-HT receptors are capable of forming homodimers when expressed alone and heterodimers when co-expressed (Xie et al. 1999; Lee

\section{Learning \& Memory}


et al. 2000). This type of association between different 5-HT receptors suggests the novel possibility that cross-talk may be possible not only at the level of second-messenger cascades, but even at the level of the receptors, adding increasing diversity to the cross-talk at the second-messenger/protein kinase cascade levels. 5-HT receptors might also be capable of interacting with receptors from other neurotransmitters (e.g., dopamine receptors) and thus allow for an unexpected level of functional diversity, by providing a point of interaction between transmission systems.

\section{Overview and Future Directions}

In order to understand the specific role of cloned 5-HT receptors in modulation of behaviors and physiological properties in Aplysia, localization of the expression of these proteins is necessary. Recently, using in situ hybridization, Barbas et al. (2003) mapped the site of expression of the two Gi-coupled receptors, 5-HT $\mathrm{Hp}_{1}$ and 5- $\mathrm{HT}_{\mathrm{ap} 2}$, in the CNS of Aplysia. Localization of expression of 5-HT receptors in neurons can also be accomplished by singlecell RT-PCR (Schacher et al. 2000; Vilim et al. 2001) or using antibodies to detect the presence of these proteins at the cell surface. Mapping of the sites of expression for all cloned 5-HT receptors will provide critical information concerning the heterogeneity of 5-HT receptor populations at the surface of presynaptic and postsynaptic neurons, and thus will ultimately allow us to study their roles in memory formation in Aplysia. These roles can be further confirmed by using RNAi and/or antisense approaches to abolish expression of specific receptors in identified neurons. For example, the neuronal circuit mediating siphon withdrawal reflex is now rather well understood, and a number of neurons within this circuit are modulated in response to 5-HT or sensitization training. It will now be possible to investigate which 5-HT receptor subtypes are expressed by SNs, interneurons, and MNs and clarify their role in memory processes.

Although exciting progress has been made in the characterization of 5-HT receptors in Aplysia, a number of subtypes likely still remain to be characterized. Early pharmacological and electrophysiological studies revealed the presence of at least six 5-HT receptor subtypes. Only four receptors, representing three different subtypes, have been cloned thus far. In particular, the molecular cascades underlying facilitation of SN-MN synapses during sensitization seem to depend on the activation of a cAMPPKA pathway by a specific Gs-coupled 5-HT receptor (Cohen et al. 2003). This receptor is certainly one important missing link in our knowledge of memory processes in Aplysia. The rapid and striking developments of molecular biological techniques that we are witnessing now will provide us with exciting new tools for further characterizing Aplysia 5-HT receptors, and thus help us further understand the complexity of the 5-HT neuromodulatory processes set in motion during memory formation.

\section{ACKNOWLEDGMENTS}

D.B. received studentships from Fonds de la Recherche en Santé du Québec (FRSQ) and from the Natural Sciences and Engineering Research Council of Canada (NSERC). V.F. and L.D.G. are supported by the Canadian Institute of Health Research (CIHR) grants MOP-14142 and MGC-57079. T.J.C. and S.M. are supported by NIH grant RO1 MH14-10183 to T.J.C. We thank C.S. Sherff and K.J. Reissner for helpful comments on an earlier version of this manuscript.

\section{REFERENCES}

Abrams, T.W., Castellucci, V.F., Camardo, J.S., Kandel, E.R., and Lloyd, P.E. 1984. Two endogenous neuropeptides modulate the gill and siphon withdrawal reflex in Aplysia by presynaptic facilitation involving cAMP-dependent closure of a serotonin-sensitive potassium channel. Proc. Natl. Acad. Sci. 81: 7956-7960.

Alberini, C.M. 1999. Genes to remember. J. Exp. Biol. 202: 2887-2891.
Angers, A., Storozhuk, M.V., Duchaîne, T., Castellucci, V.F., and DesGroseillers, L. 1998. Cloning and functional expression of an Aplysia 5-HT receptor negatively coupled to adenylate cyclase. J. Neurosci. 18: 5586-5593.

Angers, A., Fioravante, D., Chin, J., Cleary, L.J., Bean, A.J., and Byrne, J.H. 2002a. Serotonin stimulates phosphorylation of Aplysia synapsin and alters its subcellular distribution in sensory neurons. J. Neurosci. 22: $5412-5422$.

Angers, S., Salahpour, A., and Bouvier M. 2002b. Dimerization: An emerging concept for $\mathrm{G}$ protein-coupled receptor ontogeny and function. Annu. Rev. Pharmacol. Toxicol. 42: 409-435.

Antonov, I., Kandel, E.R., and Hawkins, R.D. 1999. The contribution of facilitation of monosynaptic PSPs to dishabituation and sensitization of the Aplysia siphon withdrawal reflex. J. Neurosci. 19: 1043810450.

Antonov, I., Antonova, I., Kandel, E.R., and Hawkins, R.D. 2001. The contribution of activity-dependent synaptic plasticity to classical conditioning in Aplysia. J. Neurosci. 21: 6413-6422.

. 2003. Activity-dependent presynaptic facilitation and hebbian LTP are both required and interact during classical conditioning in Aplysia. Neuron 37: 135-147.

Barbas, D., Zappulla, J.P., Angers, S., Bouvier, M., Castellucci, V.F., and DesGroseillers, L. 2002. Functional characterization of a novel serotonin receptor (5-HTap2) expressed in the CNS of Aplysia californica. J. Neurochem. 80: 335-345.

Barbas, D., Castellucci, V.F., and DesGroseillers, L. 2003. Serotonin receptors in Aplysia CNS: Role in learning and memory. Learning \& Memory meeting, abstract \#16.

Baxter, D.A. and Byrne, J.H. 1989. Serotonergic modulation of two potassium currents in the pleural sensory neurons of Aplysia. J. Neurophysiol. 62: 665-679.

. 1990. Differential effects of cAMP and serotonin on membrane current, action-potential duration, and excitability in somata of pleural sensory neurons of Aplysia. J. Neurophysiol. 64: 978-990.

Belkin, K. and Abrams, T. 1993. FMRFamide produces biphasic modulation of the LFS motor neurons in the neural circuit of the siphon withdrawal reflex of Aplysia by activating $\mathrm{Na}+$ and $\mathrm{K}+$ currents. J. Neurosci. 13: 5139-5152.

Benson, J.A. and Levitan, I.B. 1983. Serotonin increases an anomalously rectifying $\mathrm{K}+$ current in the Aplysia neuron R15. Proc. Natl. Acad. Sci. 80: $3522-3525$.

Bernier, L., Castellucci, V.F., Kandel, E.R., and Schwartz, J.H. 1982. Facilitatory transmitter causes a selective and prolonged increase in adenosine $3^{\prime}: 5^{\prime}$-monophosphate in sensory neurons mediating the gill and siphon withdrawal reflex in Aplysia. J. Neurosci. 2: 1682-1691.

Billy, A. and Walters, E. 1989. Modulation of mechanosensory threshold in Aplysia by serotonin, small cardioactive peptide B (SCPB), FMRFamide, acetylcholine and dopamine. Neurosci. Lett. 105: 200-204.

Boess, F.G. and Martin, I.L. 1994. Molecular biology of 5-HT receptors. Neuropharmacology 33: 275-317.

Bouvier, M. 2001. Oligomerization of G-protein-coupled transmitter receptors. Nat. Rev. Neurosci. 2: 274-286.

Braha, O., Dale, N., Hochner, B., Klein, M., Abrams, T.W., and Kandel, E.R. 1990. Second messengers involved in the two processes of presynaptic facilitation that contribute to sensitization and dishabituation in Aplysia sensory neurons. Proc. Natl. Acad. Sci. 87: 2040-2044.

Braha, O., Edmonds, B., Sacktor, T., Kandel, E.R., and Klein, M. 1993. The contributions of protein kinase $\mathrm{A}$ and protein kinase $\mathrm{C}$ to the actions of 5-HT on the L-type $\mathrm{Ca}^{2+}$ current of the sensory neurons in Aplysia. J. Neurosci. 13: 1839-1851.

Brembs, B., Lorenzetti, F.D., Reyes, F.D., Baxter, D.A., and Byrne, J.H. 2002. Operant reward learning in Aplysia: Neuronal correlates and mechanisms. Science 296: 1706-1709.

Bristol, A.S., Fischer, T.M., and Carew, T.J. 2001. Combined effects of intrinsic facilitation and modulatory inhibition of identified interneurons in the siphon withdrawal circuitry of Aplysia. J. Neurosci. 21: 8990-9000.

Bristol, A.S., Marinesco, S., and Carew, T.J. 2003. The neural circuit of tail-elicited siphon withdrawal in Aplysia: II. The role of gated inhibition in differential lateralization of sensitization and dishabituation. J. Neurophysiol. (in press).

Brunelli, M., Castellucci, V.F., and Kandel, E.R. 1976. Synaptic facilitation and behavioral sensitization in Aplysia: Possible role of serotonin and cyclic AMP. Science 194: 1178-1181.

Buhot, M.C. 1997. Serotonin receptors in cognitive behaviors. Curr. Opin. Neurobiol. 7:243-254.

Buhot, M.C., Patra, S.K., and Naili, S. 1995. Spatial memory deficits following stimulation of hippocampal 5-HT1B receptors in the rat. Eur. J. Pharmacol. 285: 221-228.

Buonomano, D.V., Cleary, L.J., and Byrne, J.H. 1992. Inhibitory neuron 
produces heterosynaptic inhibition of the sensory-to-motor neuron synapse in Aplysia. Brain Res. 577: 147-150.

Byrne, J.H. 1983. Identification and initial characterization of a cluster of command and pattern-generating neurons underlying respiratory pumping in Aplysia californica. J. Neurophysiol. 49: 491-508.

Byrne, J.H. and Kandel, E.R. 1996. Presynaptic facilitation revisited: State and time dependence. J. Neurosci. 16: 425-435.

Carew, T.J., Castellucci, V.F., and Kandel, E.R. 1971. An analysis of dishabituation and sensitization of the gill-withdrawal reflex in Aplysia. Int. J. Neurosci. 2: 79-98.

Carew, R.D., Hawkins, R.D., and Kandel, E.R. 1983. Differential classical conditioning of a defensive withdrawal reflex in Aplysia californica. Science 219: 397-400.

Carew, T.J., Walters, E.T., and Kandel, E.R. 1981. Associative learning in Aplysia: Cellular correlates supporting a conditioned fear hypothesis. Science 211: 501-504.

Castellucci, V.F. and Kandel, E.R. 1976. Presynaptic facilitation as a mechanism for behavioral sensitization in Aplysia. Science 194: 1176-1178.

Castellucci, V.F., Kandel, E.R., Schwartz, J.H., Wilson, F.D., Nairn, A.C., and Greengard, P. 1980. Intracellular injection of the catalytic subunit of cyclic AMP-dependent protein kinase simulates facilitation of transmitter release underlying behavioral sensitization in Aplysia. Proc. Natl. Acad. Sci. 77: 7492-7496.

Castellucci, V.F., Nairn, A.C., Greengard, P., Schwartz, J.H., and Kandel E.R. 1982. Inhibitor of adenosine $3^{\prime}: 5^{\prime}$-monophosphate-dependent protein kinase blocks presynaptic facilitation in Aplysia. J. Neurosci. 2: 1673-1681.

Castellucci, V.F., Frost, W.N., Goelet, P., Montarolo, P.G., Schacher, S., Morgan, J.A., Blumenfeld, J.H., and Kandel, E.R. 1986. Cell and molecular analysis of long-term sensitization in Aplysia. J. Physiol. (Paris) 81: 349-357.

Castellucci, V.F., Blumenfeld, J.H., Goelet, P., and Kandel, E.R. 1989. Inhibitor of protein synthesis blocks long-term behavioral sensitization in the isolated gill-withdrawal reflex of Aplysia. J. Neurobiol. 20: 1-9.

Cedar, H. and Schwartz, J.H. 1972. Cyclic adenosine monophosphate in the nervous system of Aplysia californica. II. Effect of serotonin and dopamine. J. Gen. Physiol. 60: 570-587.

Chitwood, R.A., Li, Q., and Glanzman, D.L. 2001. Serotonin facilitates AMPA-type responses in isolated siphon motor neurons of Aplysia in culture. J. Physiol. 534: 501-510.

Cleary, L.J. and Byrne, J.H. 1993. Identification and characterization of a multifunction neuron contributing to defensive arousal in Aplysia. J. Neurophysiol. 70: 1767-1776.

Cleary, L.J., Byrne, J.H., and Frost, W.N. 1995. Role of interneurons in defensive withdrawal reflexes in Aplysia. Learn. Mem. 2: 133-151.

Cleary, L.J., Lee, W.L., and Byrne, J.H. 1998. Cellular correlates of long-term sensitization in Aplysia. J. Neurosci. 18: 5988-5998.

Cohen, J.E., Onyike, C.U., McElroy, V.L., Lin, A.H., and Abrams, T.W. 2003. Pharmacological characterization of an adenylyl cyclase-coupled 5-HT receptor in Aplysia: Comparison with mammalian 5-HT receptors. J. Neurophysiol. 89: 1440-1455.

Cooper, D.M., Mons, N., and Karpen, J.W. 1995. Adenylyl cyclases and the interaction between calcium and cAMP signalling. Nature 374: $421-424$.

Critz, S., Baxter, D., and Byrne, J. 1991. Modulatory effects of serotonin, FMRFamide, and myomodulin on the duration of action potentials, excitability, and membrane currents in tail sensory neurons of Aplysia. J. Neurophys. 66: 1912-1926.

Daaka, Y., Luttrell, L.M., and Lefkowitz, R.J. 1997. Switching of the coupling of the $\beta_{2}$-adrenergic receptor to different $G$ proteins by protein kinase A. Nature 390: 88-91.

Dale, L.B., Babwah, A.V., and Ferguson, S.S. 2002. Mechanisms of metabotropic glutamate receptor desensitization: Role in the patterning of effector enzyme activation. Neurochem. Int 41: $319-326$.

Dale, N. and Kandel, E. 1990. Facilitatory and inhibitory transmitters modulate spontaneous transmitter release at cultured Aplysia sensorimotor synapses. J. Physiol. 421: 203-222.

Drolet, P., Bilodeau, L., Chorvatova, A., Laflamme, L., Gallo-Payet, N., and Payet, M.D. 1997. Inhibition of the T-type $\mathrm{Ca}^{2+}$ current by the dopamine D1 receptor in rat adrenal glomerulosa cells: Requirement of the combined action of the $G \beta \gamma$ protein subunit and cyclic adenosine 3',5'-monophosphate. Mol. Endocrinol. 11: 503-514.

Drummond, A.H., Bucher, F., and Levitan, I.B. 1980. Distribution of serotonin and dopamine receptors in Aplysia tissues: Analysis by $\left[{ }^{3} \mathrm{H}\right] \mathrm{LSD}$ binding and adenylate cyclase stimulation. Brain Res. 184: $163-177$.

Eason, M.G. and Liggett, S.B. 1995. Identification of a $\mathrm{G}_{\mathrm{s}}$ coupling domain in the amino terminus of the third intracellular loop of the $\alpha_{2 \mathrm{~A}}$-adrenergic receptor. Evidence for distinct structural determinants that confer $G_{s}$ versus $G_{i}$ coupling. J. Biol. Chem. 270: 24753-24760.
Eberly, L.B. and Pinsker, H.M. 1984. Neuroethological studies of reflex plasticity in intact Aplysia. Behav. Neurosci. 98: 609-630.

Eguchi, S., Numaguchi, K., Iwasaki, H., Matsumoto, T., Yamakawa, T., Utsunomiya, H., Motley, E.D., Owada, K.M., Hirata, Y., Marumo, F., et al. 1998. Calcium-dependent epidermal growth factor receptor transactivation mediates the angiotensin II-induced mitogen-activated protein kinase activation in vascular smooth muscle cells. J. Biol. Chem. 273: 8890-8896.

Ehrengruber, M.U., Doupnik, C.A., Xu, Y., Garvey, J., Jasek, M.C., Lester, H.A., and Davidson, N. 1997. Activation of heteromeric G protein-gated inward rectifier $\mathrm{K}+$ channels overexpressed by adenovirus gene transfer inhibits the excitability of hippocampal neurons. Proc. Natl. Acad. Sci. 94: 7070-7075.

Evans, M.L., Kadan, M.J., Hartig, P.R., and Carpenter, D.O. 1991. Correlation of ${ }^{125}$ I-LSD autoradiographic labeling with serotonin voltage clamp responses in Aplysia neurons. Synapse 8: 22-29.

Fischer, T.M. and Carew, T.J. 1993. Activity-dependent potentiation of recurrent inhibition: A mechanism for dynamic gain control in the siphon withdrawal reflex of Aplysia. J. Neurosci. 13: 1302-1314.

. 1995. Cutaneous activation of the inhibitory L30 interneurons provides a mechanism for regulating adaptive gain control in the siphon withdrawal reflex of Aplysia. J. Neurosci. 15: 762-773.

Fischer, T.M., Blazis, D.E., Priver, N.A., and Carew, T.J. 1997. Metaplasticity at identified inhibitory synapses in Aplysia. Nature 389: $860-865$.

Fischer, T.M., Yuan, J.W., and Carew, T.J. 2000. Dynamic regulation of the siphon withdrawal reflex of Aplysia californica in response to changes in the ambient tactile environment. Behav. Neurosci. 114: $1209-1222$.

Fitzgerald, K. and Carew, T.J. 1991. Serotonin mimics tail shock in producing transient inhibition in the siphon withdrawal reflex of Aplysia. J. Neurosci. 11: 2510-2518.

Frost, W.N. and Kandel, E.R. 1995. Structure of the network mediating siphon-elicited siphon withdrawal in Aplysia. J. Neurophysiol. 73: 2413-2427.

Frost, W.N., Castellucci, V.F., Hawkins, R.D., and Kandel, E.R. 1985. Monosynaptic connections made by the sensory neurons of the gilland siphon-withdrawal reflex in Aplysia participate in the storage of long-term memory for sensitization. Proc. Natl. Acad. Sci. 82: 8266-8269.

Frost, W.N., Clark, J.A., and Kandel, E.R. 1988. Parallel processing of short-term memory for sensitization in Aplysia. J. Neurobiol. 19: 297-334.

Gerhardt, C.C., and van Heerikhuizen, H. 1997. Functional characteristics of heterologously expressed 5-HT receptors. Eur. J. Pharmacol. 334: 1-23.

Gerschenfeld, H.M. and Paupardin-Tritsch, D. 1974. Ionic mechanisms and receptor properties underlying the responses of molluscan neurones to 5-hydroxytryptamine. J. Physiol. 243: 427-456.

Gerschenfeld, H.M. and Tauc, L. 1961. Pharmacological specificities of neurons in an elementary central nervous system. Nature 189: $924-925$

Ghirardi, M., Braha, O., Hochner, B., Montarolo, P.G., Kandel, E.R., and Dale, N. 1992. Roles of PKA and PKC in facilitation of evoked and spontaneous transmitter release at depressed and nondepressed synapses in Aplysia sensory neurons. Neuron 9: 479-489.

Ghirardi, M., Montarolo, P.G., and Kandel, E.R. 1995. A novel intermediate stage in the transition between short- and long-term facilitation in the sensory to motor neuron synapse of Aplysia. Neuron 14: 413-420.

Glanzman, D.L., Mackey, S.L., Hawkins, R.D., Dyke, A.M., Lloyd, P.E., and Kandel, E.R. 1989. Depletion of serotonin in the nervous system of Aplysia reduces the behavioral enhancement of gill withdrawal as well as the heterosynaptic facilitation produced by tail shock. $J$. Neurosci. 9: 4200-4213.

Goldsmith, B.A. and Abrams, T.W. 1991. Reversal of synaptic depression by serotonin at Aplysia sensory neuron synapses involves activation of adenylyl cyclase. Proc. Natl. Acad. Sci. 88: 9021-9025.

Goldsmith, D.A. and Abrams, T.W. 1992. cAMP modulates multiple K+ currents, increasing spike duration and excitability in Aplysia sensory neurons. Proc. Natl. Acad. Sci. 89: 11481-11485.

Gutkind, J.S. 1998. The pathways connecting G protein-coupled receptors to the nucleus through divergent mitogen-activated protein kinase cascades. J. Biol. Chem. 273: 1839-1842.

Hawkins, R.D. 1981a. Interneurons involved in mediation and modulation of gill-withdrawal reflex in Aplysia. II. Identified neurons produce heterosynaptic facilitation contributing to behavioral sensitization. J. Neurophysiol. 45: 315-328.

1981b. Interneurons involved in mediation and modulation of gill-withdrawal reflex in Aplysia. III. Identified facilitating neurons increase Ca2+ current in sensory neurons. J. Neurophysiol. 45: 327-339.

\section{Learning \& Memory}


Hawkins, R.D. and Schacher, S. 1989. Identified facilitator neurons L29 and L28 are excited by cutaneous stimuli used in dishabituation, sensitization, and classical conditioning of Aplysia. J. Neurosci. 9: 4236-4245.

Herrlich, A., Daub, H., Knebel, A., Herrlich, P., Ullrich, A., Schultz, G., and Gudermann, T. 1998. Ligand-independent activation of platelet-derived growth factor receptor is a necessary intermediate in lysophosphatidic acid-stimulated mitogenic activity in L cells. Proc. Natl. Acad. Sci. 95: 8985-8990.

Hochner, B. and Kandel, E.R. 1992. Modulation of a transient K+ current in the pleural sensory neurons of Aplysia by serotonin and cAMP: Implications for spike broadening. Proc. Natl. Acad. Sci. 89: $11476-11480$.

Hochner, B., Klein, M., Schacher, S., and Kandel, E.R. 1986. Additional component in the cellular mechanism of presynaptic facilitation contributes to behavioral dishabituation in Aplysia. Proc. Natl. Acad. Sci. 83: 8794-8798.

Hoyer D., Clarke, D.E., Fozard, J.R., Hartig, P.R., Martin, G.R. Mylecharane, E.J., Saxena, P.R., and Humphrey, P.P. 1994. International union of pharmacology classification of receptors for 5-hydroxytryptamine (serotonin). Pharmacol. Rev. 46: 157-203.

Jennings, K.R., Host, J.J., Kaczmarek, L.K., and Strumwasser, F. 1981. Serotonergic inhibition of afterdischarge in peptidergic bag cells. $J$. Neurobiol. 12: 579-590.

Kadan, M.J. and Hartig, P.R. 1988. Autoradiographic localization and characterization of $\left[{ }^{125} \mathrm{I}\right]$ lysergic acid diethylamide binding to serotonin receptors in Aplysia. Neuroscience 24: 1089-1102.

Kandel, E.R. 2001. The molecular biology of memory storage: A dialog between genes and synapses. Biosci. Rep. 21: 565-611.

Kanz, J.E., Eberly, L.B., Cobbs, J.S., and Pinsker, H.M. 1979. Neuronal correlates of siphon withdrawal in freely behaving Aplysia. J. Neurophysiol. 42: 1538-1556.

Kebabian, P.R., Kebabian, J.W., and Carpenter, D.O. 1979. Regulation of cyclic AMP in heart and gill of Aplysia by putative neurotransmitters dopamine and serotonin. Life Sci. 24: 1757-1764.

Kistler Jr., H.B., Hawkins, R.D., Koester, J., Steinbush, H.W., Kandel, E.R., and Schwartz, J.H. 1985. Distribution of serotonin-immunoreactive cell bodies and processes in the abdominal ganglion of mature Aplysia. J. Neurosci. 5: 72-80.

Klein, M. 1993. Differential cyclic AMP dependence of facilitation at Aplysia sensorimotor synapses as a function of prior stimulation: Augmentation versus restoration of transmitter release. J. Neurosci. 13: 3793-3801.

-1994. Synaptic augmentation by 5-HT at rested Aplysia sensorimotor synapses: Independence of action potential prolongation. Neuron 13: $159-166$.

Klein, M. and Kandel, E.R. 1980. Mechanism of calcium current modulation underlying presynaptic facilitation and behavioral sensitization in Aplysia. Proc. Natl. Acad. Sci. 77: 6912-6916.

Klein, M., Camardo, J., and Kandel, E.R. 1982. Serotonin modulates a specific potassium current in the sensory neurons that show presynaptic facilitation in Aplysia. Proc. Natl. Acad. Sci. 79: 5713-5717.

Koester, J., Mayeri, E., Liebeswar, G., and Kandel, E.R. 1973. Cellular regulation of homeostasis: Neuronal control of the circulation in Aplysia. Fed. Proc. 32: 2179-2187.

Kruger, K.E., Sossin, W.S., Saktor, T.C., Bergold, P.J., Beushausen, S., and Schwartz, J.H. 1991. Cloning and characterization of $\mathrm{Ca}(2+)$-dependent and $\mathrm{Ca}(2+)$-independent PKCs expressed in Aplysia sensory cells. J. Neurosci. 11: 2303-2313.

Lechner, H.A., Baxter, D.A., and Byrne, J.H. 2000a. Classical conditioning of feeding in Aplysia: I. Behavioral analysis. J. Neurosci. 20: 3369-3376.

. 2000b. Classical conditioning of feeding in Aplysia: II. Neurophysiological correlates. I. Neurosci. 20: 3377-3386.

Lee, S.P., Xie, Z., Varghese, G., Nguyen, T., O'Dowd, B.F., and George, S.R. 2000. Oligomerization of dopamine and serotonin receptors. Neuropsychopharmacology 23: S32-S40.

Lembo, P.M., Ghahremani, M.H., Morris, S.J., and Albert, P.R. 1997. A conserved threonine residue in the second intracellular loop of the 5-hydroxytryptamine $1 \mathrm{~A}$ receptor directs signaling specificity. Mol. Pharmacol. 52: 164-171.

Levenson, J., Byrne, J.H., and Eskin, A. 1999. Levels of serotonin in the hemolymph of Aplysia are modulated by light/dark cycles and sensitization training. J. Neurosci. 19: 8094-8103.

Li, X-C., Giot, J.F., Kuhl, D., Hen, R., and Kandel, E.R. 1995. Cloning and characterization of two related serotonergic receptors from the brain and the reproductive system of Aplysia that activate phospholipase C. J. Neurosci. 15: 7585-7591.

Linseman, D.A., Benjamin, C.W., and Jones, D.A. 1995. Convergence of angiotensin II and platelet-derived growth factor receptor signaling cascades n vascular smooth muscle cells. J. Biol. Chem. 270: 12563-12568.

Lowes, V.L., Ip, N.Y., and Wong, Y.H. 2002. Integration of signals from receptor tyrosine kinases and $\mathrm{G}$ protein-coupled receptors. Neurosignals 11: 5-19.

Luttrell, L.M. 2002. Activation and targeting of mitogen-activated protein kinases by G-protein-coupled receptors. Can. J. Physiol. Pharmacol. 80: 375-382.

Luttrell, L.M., Della Rocca, G.J., van Biesen, T., Luttrell, D.K., and Lefkowitz, R.J. 1997. G $\beta \gamma$ subunits mediate Src-dependent phosphorylation of the epidermal growth factor receptor. J. Biol. Chem. 272: 4637-4644.

Mackey, S., Glanzman, D., Small, S., Dyke, A., Kandel, E., and Hawkins, R. 1987. Tail-shock produces inhibition as well as sensitization of the siphon-withdrawal reflex of Aplysia: Possible behavioral role for presynaptic inhibition mediated by the peptide Phe-Met-Arg-Phe-NH2. Proc. Natl. Acad. Sci. 84: 8730-8734.

Mackey, S.L., Kandel, E.R., and Hawkins, R.D. 1989. Identified serotonergic neurons LCB1 and RCB1 in the cerebral ganglia of Aplysia produce presynaptic facilitation of siphon sensory neurons. $J$ Neurosci. 9: 4227-4335.

Manseau, F., Fan, X., Hueftlein, T., Sossin, W., and Castellucci, V.F. 2001. $\mathrm{Ca}^{2+}$-independent protein kinase C Apl II mediates the serotonin-induced facilitation at depressed Aplysia sensorimotor synapses. J. Neurosci. 21: 1247-1256.

Marinesco, S. and Carew, T.J. 2002. Serotonin release evoked by tail nerve stimulation in the CNS of Aplysia: Characterization and relationship to heterosynaptic plasticity. J. Neurosci. 22: 2299-2312.

Mark, M.D. and Herlitze, S. 2000. G-protein mediated gating of inward-rectifier $\mathrm{K}^{+}$channels. Eur. J. Biochem. 267: 5830-5836.

Martin, K.C., Michael, D., Rose, J.C., Barad, M., Casadio, A., Zhu, H., and Kandel, E.R. 1997. MAP kinase translocates into the nucleus of the presynaptic cell and is required for long-term facilitation in Aplysia. Neuron 18: 899-912.

Mauelshagen, J., Parker, G.R., and Carew, T.J. 1996. Dynamics of induction and expression of long-term synaptic facilitation in Aplysia. J. Neurosci. 16: 7099-7108.

Mercer, A.R., Emptage, N.J., and Carew, T.J. 1991. Pharmacological dissociation of modulatory effects of serotonin in Aplysia sensory neurons. Science 254: 1811-1813.

Michael, D., Martin, K.C., Seger, R., Ning, M.M., Baston, R., and Kandel, E.R. 1998. Repeated pulses of serotonin required for long-term facilitation activate mitogen-activated protein kinase in sensory neurons of Aplysia. Proc. Natl. Acad. Sci. 95: 1864-1869.

Montarolo, P.G., Goelet, P., Castellucci, V.F., Morgan, J., Kandel, E.R., and Schacher, S. 1986. A critical period for macromolecular synthesis in long-term heterosynaptic facilitation in Aplysia. Science 234: $1249-1254$.

Müller, U. and Carew, T.J. 1998. Serotonin induces temporally and mechanistically distinct phases of persistent PKA activity in Aplysia sensory neurons. Neuron 21: 1423-1434.

Murphy, G.G. and Glanzman, D.L. 1996. Enhancement of sensorimotor connections by conditioning-related stimulation in Aplysia depends upon postsynaptic $\mathrm{Ca}^{2+}$. Proc. Natl. Acad. Sci. 93: 9931-9936.

. 1997. Mediation of classical conditioning in Aplysia californica by long-term potentiation of sensorimotor synapses. Science 278: $467-471$.

Newlin, S.A., Schlapfer, W.T., and Barondes, S.H. 1980. Separate serotonin and dopamine receptors modulate the duration of posttetanic potentiation at an Aplysia synapse without affecting other aspects of synaptic transmission. Brain Res. 181: 89-106.

Ocorr, K.A. and Byrne, J.H. 1985. Membrane responses and changes in cAMP levels in Aplysia sensory neurons produced by serotonin, tryptamine, FMRFamide and small cardioactive peptideB (SCPB). Neurosci. Lett. 55: 113-118.

Ocorr, K.A., Tabata, M., and Byrne, J.H. 1986. Stimuli that produce sensitization lead to elevation of cyclic AMP levels in tail sensory neurons of Aplysia. Brain Res. 371: 190-192.

Pellmar, T.C. and Carpenter, D.O. 1980. Serotonin induces a voltage-sensitive calcium current in neurons of Aplysia californica. J. Neurophysiol. 44: 423-439.

Peroutka, S.J. 1994. 5-Hydroxytryptamine receptors in vertebrates and invertebrates: Why is there so many? Neurochem. Int. 25: 533-536. . 1995. 5-HT receptors: Past, present, and future. Trends Neurosci. 18: $68-69$.

Peroutka, S.J. and Howell, T.A. 1994. The molecular evolution of G protein-coupled receptors: Focus on 5-hydroxytryptamine receptors. Neuropharmacology 33: 319-324.

Pieroni, J. and Byrne, J. 1992. Differential effects of serotonin, FMRFamide and small cardioactive peptide on multiple, distributed processes modulating sensorimotor synaptic transmission in Aplysia. J. Neurosci. 12: 2633-2647.

Pieroni, J.P., Jacobowitz, O., Chen, J., and Iyengar, R. 1993. Signal recognition and integration by Gs-stimulated adenylyl cyclases. Curr. Opin. Neurobiol. 3: 345-351. 
Pinsker, H.M., Kupfermann, I., Castellucci, V.F., and Kandel, E.R. 1970. Habituation and dishabituation of the gill-withdrawal reflex in Aplysia. Science 167: 1740-1742.

Pinsker, H.M., Hening, W.A., Carew, T.J., and Kandel, E.R. 1973. Long-term sensitization of a defensive withdrawal reflex in Aplysia. Science 182: 1039-1042.

Pollock, J.D., Bernier, L., and Camardo, J.S. 1985. Serotonin and cyclic adenosine $3^{\prime}: 5^{\prime}$-monophosphate modulate the potassium current in tail sensory neurons in the pleural ganglion of Aplysia. J. Neurosci. 5: $1862-1871$.

Puente, L.G., Stone, J.C., and Ostergaard, H.L. 2000. Evidence for protein kinase C-dependent and -independent activation of mitogen-activated protein kinase in T cells: Potential role of additional diacylglycerol binding proteins. J. Immunol. 15: 6865-6871.

Purcell, A.L., Sharma, S.K., Bagnall, M.W., Sutton, M.A., and Carew, T.J 2003. Activation of a tyrosine kinase-MAPK cascade enhances the induction of long-term synaptic facilitation and long-term memory in Aplysia. Neuron 37: 473-484.

Ram, J.L., Judge, K., and Jednak, M.A. 1994. Antagonists of cholinergic and serotoninergic responses of Aplysia buccal muscle. Comp. Biochem. Physiol. Pharmacol. Toxicol. Endocrinol. 107: 235-242.

Sacktor, T.C. and Schwartz, J.H. 1990. Sensitizing stimuli cause translocation of protein kinase C in Aplysia sensory neurons. Proc. Natl. Acad. Sci. 87: 2036-2039.

Saitoh, T. and Shih, J.C. 1987. Photoaffinity labeling of adenylate cyclase-linked serotonin receptors in Aplysia neurons. J. Neurochem. 49: 1361-1366.

Schacher, S., Montarolo, P., and Kandel, E.R. 1990. Selective short- and long-term effects of serotonin, small cardioactive peptide, and tetanic stimulation on sensorimotor synapses of Aplysia in culture. J. Neurosci. 10: 3286-3294.

Schacher, S., Wu, F., Sun, Z.Y., and Wang, D. 2000. Cell-specific changes in expression of mRNAs encoding splice variants of Aplysia cell adhesion molecule accompany long-term synaptic plasticity. $J$. Neurobiol. 45: 152-161.

Sharma, S.K., Sherff, C.M., Shobe, J., Bagnall, M.W., Sutton, M.A., and Carew, T.J. 2003. Differential role of mitogen-activated protein kinase in three distinct phases of memory for sensitization in Aplysia. J. Neurosci. 23: 3899-3907.

Sholz, K.P. and Byrne, J.H. 1987. Long-term sensitization in Aplysia: Biophysical correlates in tail sensory neurons. Science 235: 685-687.

Shuster, M.J., Camardo, J.S., and Siegelbaum, S.A. 1991. Comparison of the serotonin-sensitive and $\mathrm{Ca}^{2+}$-activated $\mathrm{K}+$ channels in Aplysia sensory neurons. J. Physiol. 440: 601-621.

Siegelbaum, S.A., Camardo, J.S., and Kandel, E.R. 1982. Serotonin and cyclic AMP close single $\mathrm{K}^{+}$channels in Aplysia sensory neurones. Nature 30: 413-417.

Simen, A.A., Lee, C.C., Simen, B.B., Bindokas, V.P., and Miller, R.J. 2001. The $\mathrm{C}$ terminus of the $\mathrm{Ca}$ channel $\alpha_{1 \mathrm{~B}}$ subunit mediates selective inhibition by G-protein-coupled receptors. J. Neurosci. 21: 7587-7597.

Sossin, W.S. and Schwartz, J.H. 1992. Selective activation of $\mathrm{Ca}^{2+}$-activated PKCs in Aplysia neurons by 5-HT. J. Neurosci. 12: $1160-1168$.

Sossin, W.S., Diaz-Arrastia, R., and Schwartz, J.H. 1993. Characterization of two isoforms of protein kinase $\mathrm{C}$ in the nervous system of Aplysia californica. J. Biol. Chem. 268: 5763-5768.

Sossin, W.S., Sacktor, T.C., and Schwartz, J.H. 1994. Persistent activation of protein kinase $\mathrm{C}$ during the development of long-term facilitation in Aplysia. Learn. Mem. 1: 189-202.

Stork, P.J. and Schmitt, J.M. 2002. Crosstalk between cAMP and MAP kinase signaling in the regulation of cell proliferation. Trends Cell Biol. 12: 258-266.

Storozhuk, M. and Castellucci, V.F. 1999a. Modulation of cholinergic transmission in the neuronal network of the gill and siphon withdrawal reflex in Aplysia. Neuroscience 90: 291-301.

. 1999b. The synaptic junctions of LE and RF cluster sensory neurones of Aplysia californica are differentially modulated by serotonin. J. Exp. Biol. 202: 115-120.

Sugamori, K.S., Sunahara, R.K., Guan, H.C., Bulloch, A.G., Tensen, C.P., Seeman, P., Niznik, H.B., and Van Tol, H.H. 1993. Serotonin receptor cDNA cloned from Lymnaea stagnalis. Proc. Natl. Acad. Sci. 90: $11-15$.

Sugita, S., Goldsmith, J.R., Baxter, D.A., and Byrne, J.H. 1992. Involvement of protein kinase $\mathrm{C}$ in serotonin-induced spike broadening and synaptic facilitation in sensorimotor connections of Aplysia. J. Neurophysiol. 68: 643-651.

Sugita, S., Baxter, D.A., and Byrne, J.H. 1994. Activators of protein kinase $\mathrm{C}$ mimics serotonin-induced modulation of a voltage-dependent potassium current in pleural sensory neurons of Aplysia. J. Neurophysiol. 72: 1240-1249.
1997. Modulation of a cAMP/protein kinase A cascade by protein kinase C in sensory neurons of Aplysia. J. Neurosci. 17: 7237-7244.

Sun, Z., Kauderer, B., and Schacher, S. 1996. Differential distribution of functional receptors for neuromodulators evoking short-term heterosynaptic plasticity in Aplysia californica sensory neurons. $J$. Neurosci. 16: 7540-7549.

Sutton, M.A. and Carew, T.J. 2000. Parallel molecular pathways mediate expression of distinct forms of intermediate-term facilitation at tail sensory-motor synapses in Aplysia. Neuron 26: 219-231.

Sutton, M.A., Masters, S.E., Bagnall, M.W., and Carew, T.J. 2001. Molecular mechanisms underlying a unique intermediate phase of memory in Aplysia. Neuron 31: 143-154.

Sutton, M.A., Ide, J., Masters, S.E., and Carew, T.J. 2002. Interaction between amount and pattern of training in the induction of intermediate- and long-term memory for sensitization in Aplysia. Learn. Mem. 9: 29-40.

Thompson, J.D., Higgins, D.G., and Gibson, T.J. 1994. CLUSTAL W: Improving the sensitivity of progressive multiple sequence alignment through sequence weighting, position-specific gap penalties and weight matrix choice. Nucleic Acids Res. 22: 4673-4680.

Tierney, A.J. 2001. Structure and function of invertebrate 5-HT receptors: A review. Comp. Biochem. Physiol. A Mol. Integr. Physiol. 128: $791-804$.

Trudeau, L.E. and Castellucci, V.F. 1992. Contribution of polysynaptic pathways in the mediation and plasticity of Aplysia gill and siphon withdrawal reflex: Evidence for differential modulation. J. Neurosci. 12: $3838-3848$.

1993. Sensitization of the gill and siphon withdrawal reflex of Aplysia: Multiple sites of change in the neuronal network. J. Neurophysiol. 70: 1210-1220.

Vernier, P., Cardinaud, B., Valdenaire, O., Philippe, H., and Vincent, J.D 1995. An evolutionary view of drug-receptor interaction: The bioamine receptor family. Trends Pharmacol. Sci. 16: 375-381.

Vilim, F.S., Alexeeva, V., Moroz, L.L., Li, L., Moroz, T.P., Sweedler, J.V., and Weiss, K.R. 2001. Cloning, expression and processing of the CP2 neuropeptide precursor of Aplysia. Peptides 22: 2027-2038.

Walters, E.T. and Byrne, J.H. 1984. Posttetanic potentiation in Aplysia sensory neurons. Brain Res. 293: 377-380.

Walters, E.T., Carew, T.J., and Kandel, E.R. 1981. Associative learning in Aplysia: Evidence for conditioned fear in an invertebrate. Science 211: $504-506$

White, J.A., Ziv, I., Cleary, L.J., Baxter, D.A., and Byrne, J.H. 1993. The role of interneurons in controlling the tail-withdrawal reflex in Aplysia: A network model. J. Neurophysiol. 70: 1777-1786.

Wright, W.G., Jones, K., Sharp, P., and Maynard, B. 1995. Widespread anatomical projections of the serotonergic modulatory neuron, CB1 in Aplysia. Invert. Neurosci. 1: 173-183.

Xiao, R.P., Ji, X., and Lakatta, E.G. 1995. Functional coupling of the $\beta_{2}$-adrenoceptor to a pertussis toxin-sensitive $G$ protein in cardiac myocytes. Mol. Pharmacol. 47: 322-329.

Xie, Z., Lee, S.P., O'Dowd, B.F., and George, S.R. 1999. Serotonin 5-HT1B and 5-HT1D receptors form homodimers when expressed alone and heterodimers when coexpressed. FEBS Lett. 456: 63-67.

Xin, Y., Koester, J., Jing, J., Weiss, K.R., and Kupfermann, I. 2001. Cerebral-abdominal interganglionic coordinating neurons in Aplysia. J. Neurophysiol. 85: 174-186.

Xu, Y., Cleary, L.J., Byrne, J.H. 1994. Identification and characterization of pleural neurons that inhibit tail sensory neurons and motor neurons in Aplysia: Correlation with FMRFamide immunoreactivity. J. Neurosci. 14: 3565-3577.

Xu, Y., Pieroni, J.P., Cleary, L.J., and Byrne, J.H. 1995. Modulation of an inhibitory interneuron in the neural circuitry for the tail withdrawal reflex of Aplysia. J. Neurophysiol. 73: 1313-1318.

Zamah, A.M., Delahunty, M., Luttrell, L.M., and Lefkowitz, R.J. 2002. Protein kinase A-mediated phosphorylation of the $\beta_{2}$-adrenergic receptor regulates its coupling to Gs and Gi. Demonstration in a reconstituted system. J. Biol. Chem. 277: 31249-31256.

Zamponi, G.W. 2001. Determinants of G protein inhibition of presynaptic calcium channels. Cell Biochem. Biophys. 34: 79-94.

Zhang, F., Endo, S., Cleary, L.J., Eskin, A., and Byrne, J.H. 1997. Role of transforming growth factor- $\beta$ in long-term synaptic facilitation in Aplysia. Science 275: 1318-1320.

Zhang, L., Yu, Y., Mackin, S., Weight, F.F., Uhl, G.R., and Wang, J.B. 1996. Differential $\mu$ opiate receptor phosphorylation and desensitization induced by agonists and phorbol esters. J. Biol. Chem. 271: $11449-11454$.

\section{Learning \& Memory}




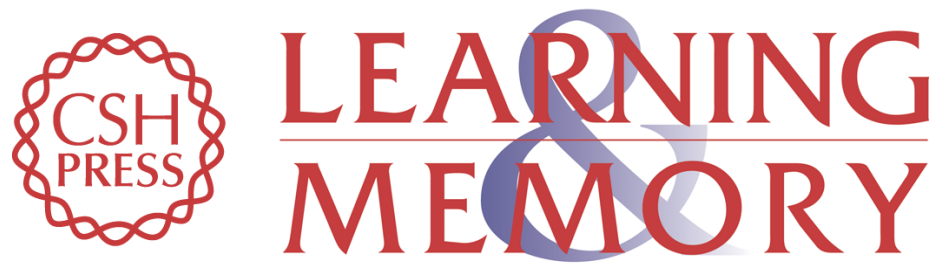

\section{Multiple Serotonergic Mechanisms Contributing to Sensitization in Aplysia: Evidence of Diverse Serotonin Receptor Subtypes}

Demian Barbas, Luc DesGroseillers, Vincent F. Castellucci, et al.

Learn. Mem. 2003, 10:

Access the most recent version at doi:10.1101/lm.66103

References This article cites 168 articles, 86 of which can be accessed free at: http://learnmem.cshlp.org/content/10/5/373.full.html\#ref-list-1

License

Email Alerting

Receive free email alerts when new articles cite this article - sign up in the box at the Service top right corner of the article or click here. 